University of Nebraska - Lincoln

DigitalCommons@University of Nebraska - Lincoln

$1-17-2020$

\title{
Insights about Diversity of Tetrabothriidae (Eucestoda) among Holarctic Alcidae (Charadriiformes): What Is Tetrabothrius jagerskioeldi?
}

\author{
Eric P. Hoberg \\ University of New Mexico, geocolonizer@gmail.com \\ Kaylen Marie Soudachanh \\ University of New Mexico
}

Follow this and additional works at: https://digitalcommons.unl.edu/manter

Part of the Biodiversity Commons, Ornithology Commons, Parasitology Commons, and the Zoology Commons

Hoberg, Eric P. and Soudachanh, Kaylen Marie, "Insights about Diversity of Tetrabothriidae (Eucestoda) among Holarctic Alcidae (Charadriiformes): What Is Tetrabothrius jagerskioeldi?" (2020). MANTER: Journal of Parasite Biodiversity. 11.

https://digitalcommons.unl.edu/manter/11

This Article is brought to you for free and open access by the Parasitology, Harold W. Manter Laboratory of at DigitalCommons@University of Nebraska - Lincoln. It has been accepted for inclusion in MANTER: Journal of Parasite Biodiversity by an authorized administrator of DigitalCommons@University of Nebraska - Lincoln. 


\title{
Insights about Diversity of Tetrabothriidae (Eucestoda) among Holarctic Alcidae (Charadriiformes): What Is Tetrabothrius jagerskioeldi?
}

\author{
Eric P. Hoberg and Kaylen Marie Soudachanh
}

Museum of Southwestern Biology, Department of Biology, University of New Mexico, Albuquerque, New Mexico, USA

Corresponding author - Eric P. Hoberg, Museum of Southwestern Biology, Department of Biology, University of New Mexico, Albuquerque, NM, 87131 USA, email geocolonizer@gmail.com

\begin{abstract}
Tetrabothriid cestodes are characteristic helminths that infect species of seabirds globally. We begin with the exploration of the diversity of tapeworms of the genus Tetrabothrius Rudolphi, 1819 (Eucestoda: Tetrabothriidae), some of which are distributed among seabirds of the family Alcidae (Charadriiformes) at boreal to higher latitudes of Holarctic seas. During the course of 2 decades of field inventory from 1975 through the early 1990s (in addition to earlier collections assembled by Robert L. Rausch and colleagues in Alaska initiated in the late 1940s), an extensive series of tapeworm specimens attributable to species of Tetrabothrius was recovered from seabirds across the North Pacific Basin. It was assumed based on published records of species richness in this fauna that a single species, Tetrabothrius jagerskioeldi Nybelin, 1916, would predominate among alcid hosts. In contrast, detailed study revealed considerable morphological complexity that could not be accommodated within a single species. Further, it was apparent that the limits for the primary morphological attributes of T. jagerskioeldi were not clearly defined. We redescribe T. jagerskioeldi based on direct examination of the type series of specimens from Sweden and an assemblage of specimens largely from alcid hosts from the North Pacific basin. Specimens of T. jagerskioeldi are diagnosed by a characteristic configuration of the genital atrium, position of the male and female genital canals, structure of the male and female organ systems, and numbers of testes. Based on the spectrum of characters we explored, it was apparent that numerous specimens of Tetrabothrius among genera and species of Alcidae from the North Pacific inventory could not be accommodated in T. jagerskioeldi and provisionally are referred to Tetrabothrius undescribed n. sp. pending ongoing evaluations. Superficially, these are all large and robust tapeworms referable to Tetrabothrius, potentially contributing to misidentifications and misattribution that have occurred both in the literature and in the few archived specimens in museums. We summarize the results of extensive inventory collections since 1950, establishing a distributional baseline for species of Tetrabothrius from a wide range of geographic localities and an assemblage of host species among the Alcidae and some species of Laridae, Stercorariidae, and Phalacrocoracidae. We further
\end{abstract}


evaluate the validity of historical published records for T. jagerskioeldi and other congeners among alcids and other seabirds. A conclusion that emerges is that T. jagerskioeldi is a rare tapeworm with a patchy distribution in pelagic to nearshore marine environments, showing considerable heterogeneity in space and time, among alcid seabirds across high-latitude seas of the Holarctic. Prior concepts for host range require reevaluation. We demonstrate that the associations for $T$. jagerskioeldi are relatively narrow and appear to involve a more limited spectrum of alcid hosts, and less often other species of marine birds, than currently assumed. A robust understanding of parasite species diversity and distribution is critical in establishing baselines across marine ecosystems. Our current study among species of Tetrabothrius, especially in the North Pacific basin and Bering Sea ecosystem contributes to development of a series of specimen-centered baselines derived primarily from the late 1970 s to the early 1980 s against which accelerating perturbations linked to climate warming and ocean-atmosphere interactions may be explored. Detailed knowledge of specimenbased faunal diversity for parasites provides a cumulative, temporal, and spatial snapshot and proxy for conditions in marine foodwebs and the continuity of trophic linkages.

Keywords: Tetrabothrius jagerskioeldi, Alcidae, macroparasites, marine diversity, specimen archives, comparative morphological, host, geographical baselines

\section{Introduction}

Helminth parasites of seabirds hold substantial information about the status and sustainability of marine ecosystems (Hoberg, 1996; Muzaffar, 2009). Species diversity, host range and geographic distribution are driven by climatological, oceanographic, and anthropogenic factors that influence the structure of trophic linkages on which parasite life cycles and transmission dynamics are dependent (Galaktionov, 1995; Hoberg, 1996; 2005). Consequently, parasites serve as direct indicators and as proxies for conditions in marine foodwebs over evolutionary and ecological time (e.g., Hoberg and Brooks, 2008; Hoberg et al., 2013). Parasite distributions demonstrate the outcomes of often subtle oscillations in atmospheric and sea-surface temperature, including regime shifts such as those of the El Niño Southern Oscillation and the Pacific Decadal Oscillation that initiate cascades in marine foodwebs on varying spatial and temporal scales (Mouritsen and Poulin, 2002; Chavez et al., 2003; Hurrell et al., 2003; Sydeman et al., 2015; Hoberg et al., 2017).

Insights about the diversity of parasites in marine birds (and other vertebrates) depend on the development of robust information on expansive spatial and temporal scales. Baselines for biodiversity information, transcending populations to species and ecosystems, emerge from field collections and archival deposition of specimens in permanent museum repositories (e.g., Cook et al., 2013, 2017; Hoberg et al., 2013; Brooks et al., 2014; Dunnum et al., 2017). Specimens in synergy with their associated data constitute the fabric of biodiversity informatics, becoming the gateway to explore dynamic change in the biosphere. Archives of specimens and information are the cornerstones to reveal ecological connectivity and perturbation emerging from the acceleration of climate forcing, other anthropogenic factors, and natural events. Parasite faunal baselines will contribute to identifying and understanding the scope of ecological perturbation, including shifting production cycles, trophic dynamics, and mortality events emerging across the Bering Sea ecosystem and broader North Pacific ba$\sin$ (e.g., Jones et al., 2019).

At the core of biodiversity informatics is the accurate identification of species. In the current paper we begin the exploration of the diversity of tapeworms of the genus Tetrabothrius Rudolphi, 1819 (Eucestoda: Tetrabothriidae), some of which are distributed among seabirds of the family Alcidae (Charadriiformes) at boreal to higher latitudes of Holarctic seas. The Alcidae is a small avian group including 24 extant species with an extended history during the late Tertiary in marine environments of the Northern Hemisphere (e.g., Moum et al., 1994; Friesen et al., 1996; Smith, 2011). Conventional wisdom for tetrabothriids is that a single species, Tetrabothrius jagerskioeldi Nybelin, 1916, among 52 recognized congeners (Mariaux et al., 2017), is geographically widespread across polar and boreal seas and occurs within a considerable number of the 24 extant species of alcids representing multiple avian tribes (e.g., Baer, 1954; Temirova and Skrjabin, 1978; Hoberg, 1984; Muzaffar and Jones, 2004). Baer (1954) proposed synonymy 
for Tetrabothrius intrepidus Baylis, 1919 with T. jagerskioeldi, reinforcing the concept for a broad geographic and host distribution.

During the course of 2 decades of field inventory from 1975 through the early 1990s (in addition to earlier collections assembled by Robert L. Rausch and colleagues in Alaska initiated in the late 1940s), an extensive collection of tapeworms attributable to species of Tetrabothrius was recovered from seabirds across the greater North Pacific Basin (e.g., Hoberg, 1984; Table 1; Supplementary Data Table 1; Supplementary Data Table 2). During the 1990s, focused investigations of diversity in this assemblage of specimens, primarily in seabirds of the families Alcidae and Laridae, were initiated but not brought to completion. It was assumed at that time, based on published records of species richness in this fauna, that a single species, Tetrabothrius jagerskioeldi, would predominate among alcid hosts.

In contrast, detailed study revealed considerable morphological complexity that could not be accommodated within a single species. Further, the limits for the primary morphological attributes of $T$. jagerskioeldi were not clearly defined. Characterization of morphology tended to be incomplete or ambiguous, and this was a common theme in the original description by Nybelin (1916) and in subsequent examinations and redescriptions of tapeworms attributed to this species from localities primarily in the North Atlantic Basin and Arctic Ocean (e.g., Baer, 1954; Temirova and Skrjabin, 1978). Some descriptions were repeated across multiple publications (e.g., Temirova and Skrjabin, 1978; Ryzhikov et al., 1985). Further, published reports of species occurrence across high latitude seas were generally not accompanied by specimens and comparative morphological evaluations (e.g., Belopol'skaia, 1952, 1963a, 1963b; Baer, 1956; Threlfall, 1971; Smetanina 1979, 1981; Smetanina and Leonov, 1984). Despite records of T. jagerskioeldi in a relatively broad literature which established an apparent Holarctic range, specimens of this and other species of Tetrabothrius were rarely archived, even from very extensive inventories, as vouchers in museum repositories (e.g., Threlfall, 1971; Muzaffar and Jones, 2004; Muzaffar, 2009). Consequently, the potential was limited for comparative studies linking taxonomy and identification with the spatial and temporal aspects of distribution. An essential question requiring resolution, and as a requisite gateway to definitions of diversity within this fauna, was the following: What is T. jagerskioeldi, its host range, and geographic distribution?
As the foundation to resolve the identity of $T$. jagerskioeldi, and thus to provide a pathway for defining morphologically based species limits within an apparent complex of cryptic species, the original type specimens held in the Naturhistoriska Museet, Göteborg, Sweden, were examined. Other specimens attributed to T. jagerskioeldi in the collections of the Museum d'Histoire Naturelle, Geneva, Switzerland, were evaluated. Additionally, the type series of $T$. intrepidus Baylis, 1919, an apparent synonym of $T$. jagerskioeldi, held at the British Museum of Natural History was studied. Other specimens of Tetrabothrius in alcid hosts, but which were unattributed to species, were also examined from the Museum National d'Histoire Naturelle, Paris. New data derived from these specimens is presented in the context of standardized approaches recognizing progressive ontogenetic changes in the strobila, proglottids, and organ systems to define structural diversity in the Tetrabothriidae (e.g., Murav'eva and Popov, 1976; Hoberg, 1987; Hoberg et al., 1991). The identity of T. jagerskioeldi is now firmly established and is explored in our current study. Relative to field inventory across the North Pacific, the occurrence of $T$. jagerskioeldi was confirmed, whereas multiple previously unrecognized cryptic species partitioned among the alcids were revealed (Supplementary Data Table 2).

Our current study focuses on a complete redescription and definition for T. jagerskioeldi as a comparative morphological baseline. We report the first specimens and observations of $T$. jagerskioeldi confirmed in host species and localities from the North Pacific Basin, Bering Sea, and Sea of Okhotsk. New hosts and geographic records are documented by archival specimens from the region of the North Pacific Basin. Further, we summarize the results of extensive inventory collections since 1950 establishing a distributional baseline for species of Tetrabothrius from a wide range of geographic localities and an assemblage of host species among the Alcidae and some species of Laridae, Stercorariidae, and Phalacrocoracidae (Table 1; Supplementary Data Table 1; Supplementary Data Table 2). We further evaluate the validity of historical published records for T. jagerskioeldi and other congeners among alcids and other seabirds. In providing a firm foundation for T. jagerskioeldi, we establish the basis for a series of taxonomic decisions and descriptions to characterize previously unrecognized diversity among species of Tetrabothrius, primarily associated with alcid host species, that will build and follow on our current study. 
Table 1. Avian Specimens (Alcidae, Laridae, Stercorariidae, and Phalacrocoracidae) from the Greater North Pacific Basin Examined for Helminth Parasites (1949-1992)

\begin{tabular}{|c|c|c|c|}
\hline Species & Number & \multicolumn{2}{|c|}{ Number } \\
\hline \multicolumn{2}{|l|}{ Charadriiformes-Alcidae } & \multicolumn{2}{|l|}{ Charadriiformes-Laridae } \\
\hline Tribe Alcini & & Rissa tridactyla (Linnaeus) (black-legged kittiwake) & 206 \\
\hline Alle alle (Linnaeus) (dovekie) & 1 & Rissa brevirostris (Bruch) (red-legged kittiwake) & 2 \\
\hline Uria aalge (Pontoppidan) (common murre) & 275 & Larus hyperboreous Gunnerus (glaucous gull) & 13 \\
\hline Uria lomvia (Linnaeus) (thick-billed murre) & 150 & Larus glaucescens (Naumann) & \\
\hline \multicolumn{2}{|l|}{ Tribe Cepphini } & (glaucous-winged gull) & 65 \\
\hline Cepphus carbo Pallas (spectacled guillemot) & 4 & Larus schistisagus Stejneger (slaty-backed gull) & 27 \\
\hline Cepphus columba Pallas (pigeon guillemot) & 22 & Larus argentatus (Pontoppidan) (herring gull) & 12 \\
\hline Cepphus grylle (Linnaeus) (black guillemot) & 8 & Larus heermani Cassin (Heerman's gull) & 6 \\
\hline \multicolumn{2}{|l|}{ Tribe Brachyramphini } & Sterna paradisaea Pontoppidan (Arctic tern) & 37 \\
\hline \multicolumn{2}{|l|}{ Brachyramphus marmoratus (Gmelin) } & Onychoprion aleutica (Baird) (Aleutian tern) & 1 \\
\hline (marbled murrelet) & 7 & Xema sabini (Sabine) (Sabine's gull) & 34 \\
\hline \multicolumn{4}{|l|}{ Brachyramphus brevirostris (Vigors) (Kittlitz's } \\
\hline murrelet) & 3 & Charadriiformes-Stercorariidae & \\
\hline \multicolumn{2}{|l|}{ Tribe Synthliboramphini } & Stercorarius pomarinus Temminck (pomarine jaeger) & 14 \\
\hline \multicolumn{2}{|l|}{ Synthliboramphus antiquus (Gmelin) } & Stercorarius parasiticus (Linnaeus) (parasitic jaeger) & 4 \\
\hline (ancient murrelet) & 50 & Stercorarius longicaudus Vieillot (long-tailed jaeger) & 18 \\
\hline \multicolumn{4}{|l|}{ Synthliboramphus scrippsi (Green and Arnold) } \\
\hline (Scripp's murrelet) & 4 & Suliformes-Phalacrocoracidae & \\
\hline \multicolumn{2}{|l|}{ Tribe Aethiini } & Urile pelagicus (Pallas) (pelagic shag) & 23 \\
\hline Ptychoramphus aleuticus Brandt (Cassin's auklet) & 16 & Urile "kenyoni" (Siegel-Causey) (Kenyon's shag) & \\
\hline Aethia psittacula (Pallas) (parakeet auklet) & 56 & $=U \cdot$ pelagicus & 2 \\
\hline Aethia cristatella (Pallas) (crested auklet) & 190 & Urile urile (Gmelin) (red-faced shag) & 28 \\
\hline Aethia pygmaea (Gmelin) (whiskered auklet) & 18 & & \\
\hline Aethia pusilla (Pallas) (least auklet) & 62 & Specimens Examined & 1,826 \\
\hline \multicolumn{2}{|l|}{ Tribe Fraterculini } & Species Examined & 34 \\
\hline Cerorhinca monocerata (Pallas) (rhinoceros auklet) & 39 & & \\
\hline Fratercula cirrhata (Pallas) (tufted puffin) & 285 & & \\
\hline Fratercula corniculata (Naumann) (horned puffin) & 144 & & \\
\hline
\end{tabular}

\section{Methods and Materials}

\section{Correct Nomenclature}

These large cestodes, primarily among the Alcidae, are often shown under the spelling of T. jagerskioldi or T.jagerskiöldi, which is most prevalent in common usage (e.g., Yamaguti, 1959; Schmidt, 1986; Temirova and Skrjabin, 1978; Muzaffar and Jones, 2004). This nomenclature is incorrect according to Article 32 of the 4th Edition of the International Code of Zoological Nomenclature (ICZN, 1999). Nybelin (1916) presented the original spelling as Tetrabothrius jägerskiöldi, the species name accepted by Fuhrmann (1932), Joyeux and Baer (1936), and Baer (1954, 1956). The correct spelling, as shown by Ryzhikov et al. (1985) and Mariaux et al. (2017), and accepted in the current manuscript, is Tetrabothrius jagerskioeldi.

\section{Primary Collection Localities North Pacific Basin}

Alaska: Aleutian Islands region, Bering Sea region, Arctic Basin and Chukchi Sea, Gulf of Alaska region; Eastern North Pacific: California and Washington State; Russian Subarctic and Arctic: Northern Sea of Okhotsk, East Siberian Sea, and Chaun Gulf. Host species and specimens examined are summarized in Table 1 and include 18 species of Alcidae, 10 Laridae, 3 Stercorariidae, and 3 Phalacrocoracidae. Complete localities, dates, and collectors for field-based biodiversity inventory are outlined in Supplementary Data Table 1. Specimens confirmed and attributed to T. jagerskioeldi from these localities and hosts have been archived in the Parasite Division of the Museum of Southwestern Biology, University of New Mexico, as specified in Supplementary Data Table 2 and Supplementary Data Table 3. 
Additionally, for discussion in the text the geographic coordinates and place names for localities of seabird colonies and Nature Reserves (Zapovednika) originally reported in the Russian literature are amended for clarity. (1) The Sudzukhinsky Zapovednik is a former name of the Lazovsky Zapovednik, which is located in the south of Primorskiy Krai, Russian Far East $\left(43^{\circ} 14^{\prime} 0^{\prime \prime} \mathrm{N}, 133^{\circ} 24^{\prime} \mathrm{O}^{\prime \prime} \mathrm{E}\right)$ and is the site of collections reported by Belopol'skaia (1963a, 1963b). (2) Peter the Great Bay, Russian Far East, adjacent to Vladivostok $\left(42^{\circ} 40^{\prime} \mathrm{N}, 132^{\circ} 00^{\prime} \mathrm{E}\right)$ is the site of collections reported by Smetanina $(1979,1981)$. (3) Kharlov Island Barents Sea, Russia $\left(68^{\circ} 48^{\prime} 25^{\prime \prime} \mathrm{N}, 37^{\circ} 20^{\prime} 37^{\prime \prime} \mathrm{E}\right)$ is the largest island of the Seven Islands Archipelago and site of collections summarized by Galkin et al. (2005). Seven Islands is adjacent to the Kola (Kolskiy) Peninsula coast, Barents Sea (the coast of the Kola Peninsula to the east of the Kola Fjord is called East Murman), and the site of the largest seabird colonies in this region. (4) The Seven Islands State Natural Reserve (Sem' Ostrov Gosudarstvennogo Zapovednik) was the site of collections reported by Belopol'skaia (1952) based on field work in the early 1940s. In the 1960s the Seven Islands State Natural Reserve was incorporated into the Kandalaksha State Natural Reserve (Kandalakshskiy Gosudarstvennogo Zapovednik). (5) Bezymiannaya Bay, Novaya Zemlya, Russian Arctic $\left(72^{\circ} 54^{\prime} \mathrm{N}, 53^{\circ} 10^{\prime} \mathrm{E}\right)$ is the site of collections reported by Markov (1941). (5) Hooker Island, is in the archipelago defined by Franz Josef Land in the high Arctic $\left(80^{\circ} 18^{\prime} \mathrm{N}, 53^{\circ} 21^{\prime} \mathrm{E}\right)$ and is the site of collections reported by Galkin et al. (2005).

\section{Specimens Examined}

\section{Tetrabothrius jagerskioeldi Nybelin, 1916}

Type series - consisting of 5 slides held in the Naturhistoriska Museet, Göteborg, Sweden, in a series prepared and described by Orvar Nybelin in 1916 based on specimens collected by L. A. Jägerskiöld in a black guillemot, Cepphus grylle (Linnaeus), at Bohuslän, Kristineberg, Sweden (ca. $\left.58^{\circ} 14^{\prime} \mathrm{N}, 11^{\circ} 22^{\prime} \mathrm{E}\right)$, on 28 July 1910 (Nybelin, 1916). These included 3 slides marked "type" respectively-a whole mount with 5 segments, transverse sections from mature, and transverse sections from gravid; 2 additional slides not marked "type" but from the same host and locality included frontal sections of mature proglottids and transverse sections of early mature proglottids. Voucher series - Additionally an early mature specimen was collected by $\mathrm{O}$. Nybelin on 18 July 1916 in C. grylle at Bohuslän, Väderöarna (Weather
Islands Archipelago), Sweden (ca. 58 $34^{\prime} \mathrm{N}, 11^{\circ} 03^{\prime} \mathrm{E}$ ) (labeled No. 1916-2915) but was held in ethanol and not mounted or included in the original description. In February 1995 this specimen was processed for examination. In total 4 slides were prepared, with strobila or sections stained in Semichon's acetic carmine, and mounted in Canada balsam: (1) 25 proglottids were cut from the terminal end of the cestode for preparation of hand-cut, transverse thick sections; (2) anterior of the remaining strobila with scolex was mounted dorsally; (3) 5 proglottids were mounted ventrally; (4) 6 mature proglottids were mounted dorsally, with the tegument removed to facilitate viewing of internal anatomy.

Other Material: (1) 2 specimens on 1 slide attributed to this species held in the Museum d'Histoire Naturelle, Geneva (No. 108/60), collected by J. G. Baer on 27 July 1955 from near Kangerluk (formerly Diskofjord), West Greenland (ca. $69^{\circ} 29^{\prime} \mathrm{N}, 53^{\circ} 56^{\prime} \mathrm{W}$ ) in Cepphus grylle are determined to represent an undescribed species (E. P. Hoberg, unpublished data). (2) 1 specimen on 3 slides attributed to this species held in the Museum d'Histoire Naturelle, Geneva (No. 108/61-63), collected by J. G. Baer on 6 August 1955 from Oqaitsoq (near Disko Island), West Greenland (ca. $69^{\circ} 55^{\prime} \mathrm{N}, 51^{\circ} 22^{\prime} \mathrm{W}$ ) in a razorbill, Alca torda Linnaeus, is redetermined as T. erostris (Lönnberg, 1896) in the current study (E. P. Hoberg, unpublished data).

\section{Tetrabothrius intrepidus Baylis, 1919 [Confirmed as junior synonym of $T$. jagerskioeldi consistent with Baer, 1954]}

Type series - consisting of 4 slides held in the British Museum of Natural History (1919.6.14.24) collected by E. A. Cockayne on 27 June 1917 in Cepphus grylle from "Yukanski," Kola Peninsula, Russia (apparently in the Yukanski Islands, adjacent to Ostrovny, Russia, ca. $68^{\circ} 3^{\prime} \mathrm{N}$, $39^{\circ} 30^{\prime} \mathrm{E}$ ), and described by H. A. Baylis (1919). Subsequently, 4 slides were prepared in November 1995 from ethanol-preserved specimens in the type series, including hand-cut thick sections to study the genital atrium.

Other Material: (1) A specimen attributed to T. intrepidus held in the Museum d'Histoire Naturelle, Geneva (No. 65/72-73), from Reykjavik, Iceland (ca. $64^{\circ} 09^{\prime} \mathrm{N}$, $21^{\circ} 57^{\prime} \mathrm{W}$ ), in Cepphus grylle appears consistent with the original description. (2) Additional specimens held in the British Museum and attributed to T. intrepidus in Uria aalge (Pontoppidan) under 1976.4.21.80 collected by G. Rees adjacent to Cardiganshire, Wales, United Kingdom (ca. $51^{\circ} 35^{\prime} \mathrm{N}, 3^{\circ} 45^{\prime} \mathrm{W}$ ) and 1984.10.15.1-6 collected by J. Vercruysse, presumably in the North Sea adjacent to the 
Netherlands, are referable to Tetrabothrius erostris (E. P. Hoberg, unpublished data). (3) Unattributed specimens in Uria aalge [reported as Uria troile (Linnaeus)] from the coastal region of Concarneau, France (ca. $47^{\circ} 51^{\prime} \mathrm{N}$, $3^{\circ} 55^{\prime} \mathrm{W}$ ), held in the Museum National d'Histoire Naturelle, Paris, were also examined, with new slides prepared; these specimens were also consistent with $T$. erostris (E. P. Hoberg, unpublished data).

\section{North Pacific Basin/Sea of Okhotsk Vouchers - E. P. Hoberg, R. L. Rausch, and colleagues}

Specimens of Tetrabothrius were examined based on field collections of 1,826 avian specimens representing 34 species across 43 geographic localities in the North Pacific Basin and East Siberian Sea. Complete data for hosts, localities, and dates of collection are summarized (Table 1; Supplementary Data Tables 1 and 2). Complete specimen data and identification of T. jagerskioeldi and other species are documented, along with data for deposition in the Division of Parasitology and collections of the Museum of Southwestern Biology, University of New Mexico, Albuquerque, NM (Supplementary Data Table 3) (http://arctos.database.museum). Identifications and species attributions for this series of specimens were limited to comparative morphological approaches. Molecular phylogenetic analyses were not possible for specimens because of their age and time frames for field collections in the 1950 s to late 1980s, and a long history of storage at ambient temperatures in $10 \%$ formalin, varying grades of ethanol, and other reagents.

\section{Results}

\section{Identity of T. jagerskioeldi in Historical Collections}

Excluding the type series for T. jagerskioeldi and T. in trepidus, few specimens were available in museum repositories representing North America and Eurasian collections (Table 2; Table 3). The identity and disposition of these specimens has been outlined under the section above exploring specimens examined during our study. Among these, a single specimen of T. jagerskioeldi (attributed to T. intrepidus) was confirmed in C. grylle from Reykjavik, Iceland. A series of 6 specimens from 5 localities were misidentified (referred to incorrect species) or misattributed (not recognized as undescribed). These include 3 specimens in $U$. aalge from western Europe and a single specimen in Alca torda from West Greenland, all attributable to T. erostris. Additionally, 2 specimens in C. grylle from West Greenland are consistent with a currently undescribed species of Tetrabothrius. The majority of reports in the literature were not accompanied by deposition of voucher specimens.

\section{Distribution of Tetrabothrius spp. in the North Pa- cific Inventory}

Specimens of Tetrabothrius were examined based on field collections of 1,826 marine birds of 34 species from 7 regions and 43 localities across the greater North Pacific Basin (Table 1, Supplementary Data Table 1, Supplementary Data Table 2). Collections included 1,334 alcids of 18 species, 403 larids (10 species), 36 stercorariids (3 species), and 53 phalacrocoracids (3 species). Overall species of Tetrabothrius were distributed in 349 hosts (not accounting for multispecies infections) among 1,826 seabirds examined (prevalence $=19 \%$ ). We confirmed the identity of T. jagerskioeldi in alcid (6 species), larid (1), and phalacrocoracid (1) hosts based on these collections and direct comparisons to the type series of Nybelin (1916) (Table 2; Supplementary Data Table 2; Supplementary Data Table 3).

Specimens of T. jagerskioeldi occurred in 29 of 1,826 birds (overall, $1.5 \%$ prevalence). Infections were observed primarily among alcid hosts, including 6 of 18 species examined at 7 of 43 localities and among 14 of 1,334 avian specimens ( $1 \%$ prevalence; range in intensity $=1-9$ per host) (Table 3; Supplementary Data Table 2). Infections of $T$. jagerskioeldi were most often observed among guillemots, including C. columba (22 examined, 8 infected, 37\% prevalence), C. grylle (8 examined, 1, 12.5\%), and C. carbo (4 examined, 2, 50\%). Other alcids were rarely observed as hosts, with cestodes occurring in single specimens of $U$. aalge at Shuyak Island (275 examined, $1,<1 \%)$, B. marmoratus at Kodiak Island (7 examined, 1, 14.5\%), and C. monocerata in pelagic environments south of the Aleutian Islands (39 examined, 1, 2.5\%).

Among non-alcid hosts, $T$. jagerskioeldi occurred in 15 of 492 avian specimens examined (3\% prevalence) at 3 of 43 localities; it was not observed in stercorariids. Among larids, 14 of 403 specimens (3.5\% prevalence; range in intensity $=1-4$ ) in 1 of 10 species were hosts across 2 of 43 localities, with T. jagerskioeldi observed in Larus glaucescens (Naumann) from the northern Gulf of Alaska. Among glaucous-winged gulls, 10 of 20 (prevalence $=50 \%$ ) were hosts at Puffin Island, and 4 of 20 (20\%) at Central Island. Among phalacrocoracids, 1 of 53 specimens (1.9\%) among 3 species was a host at a single locality, with a single specimen of $T$. jagerskioeldi observed in Urile pelagicus (Pallas) at Buldir Island from the far western Aleutian Islands. 


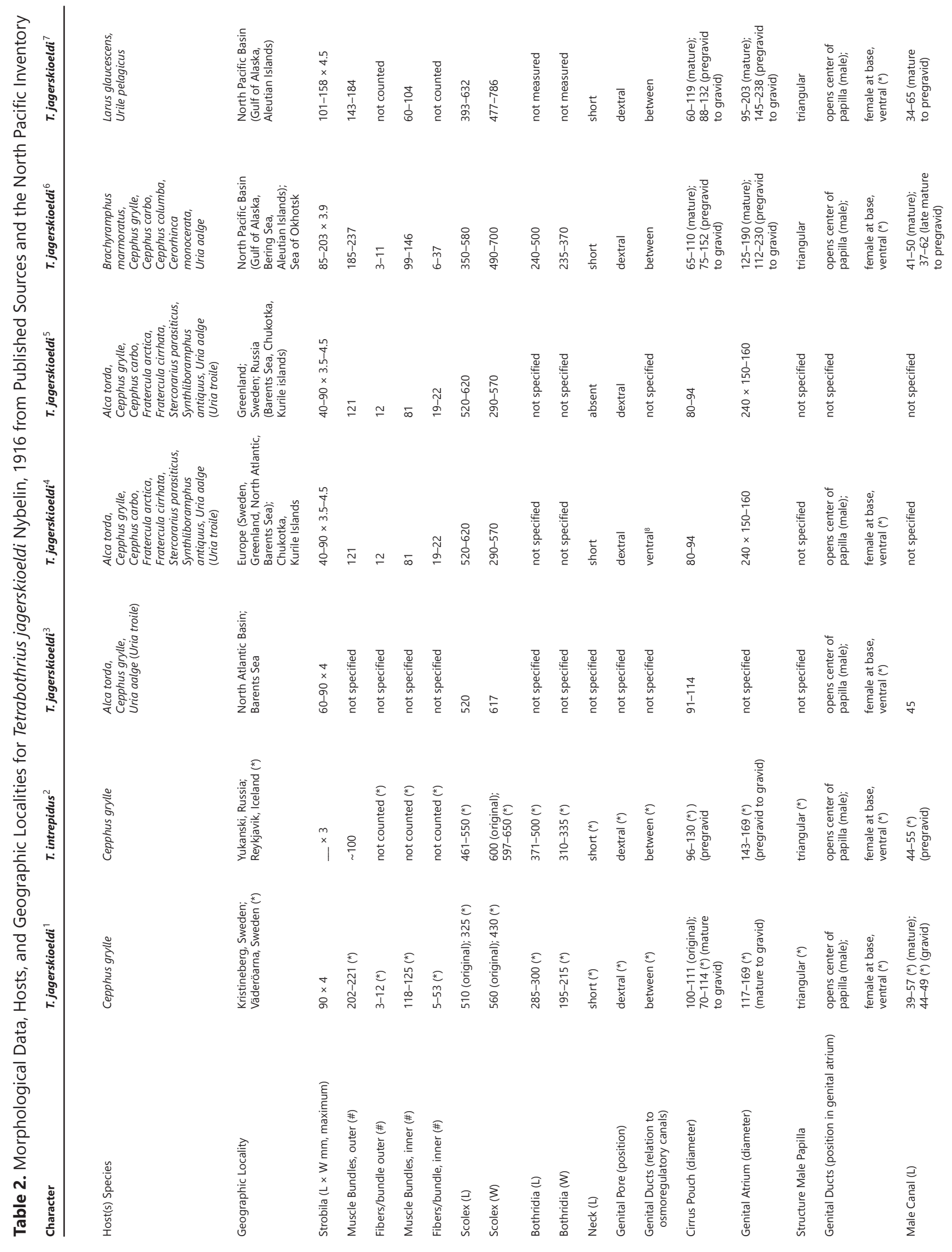




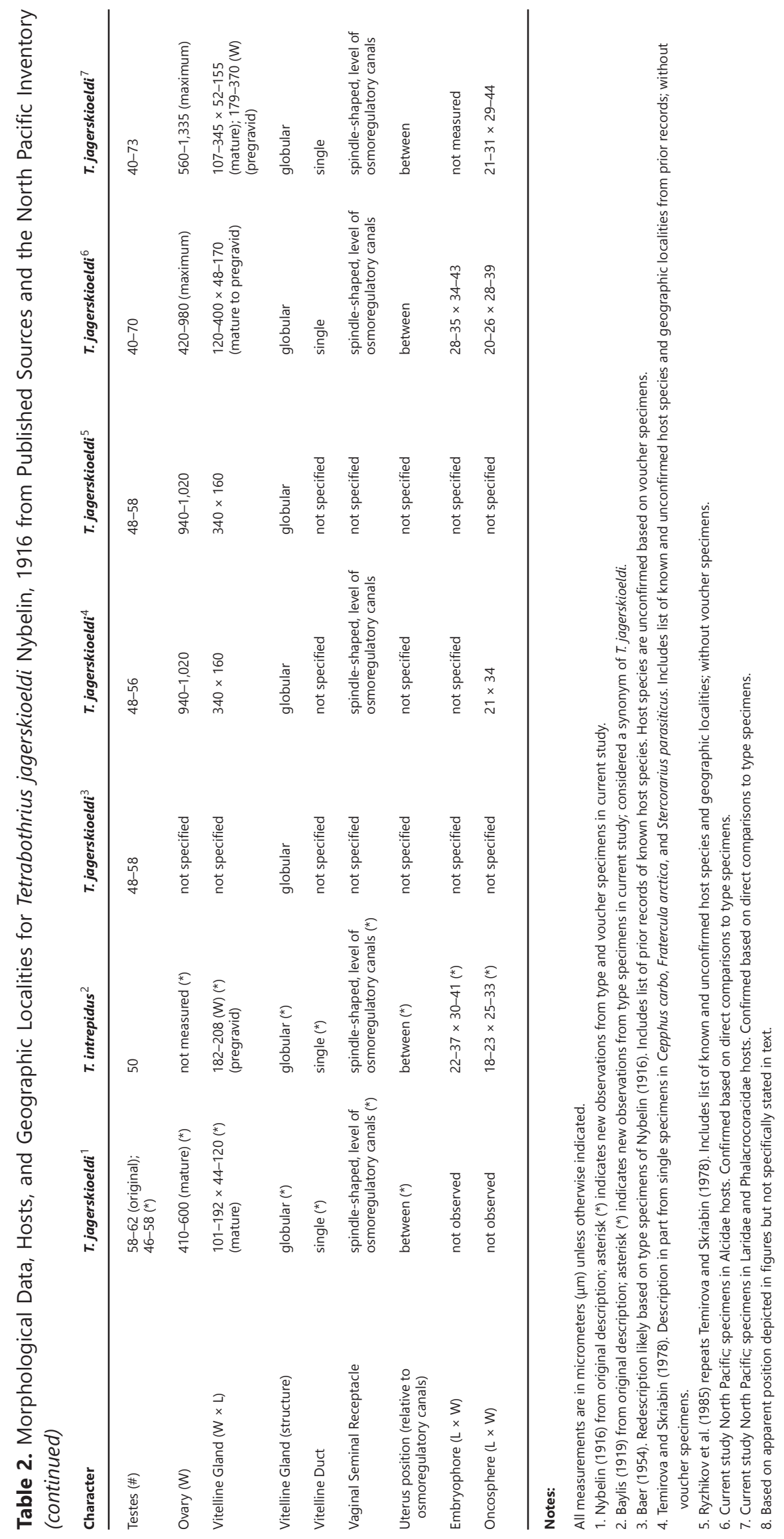




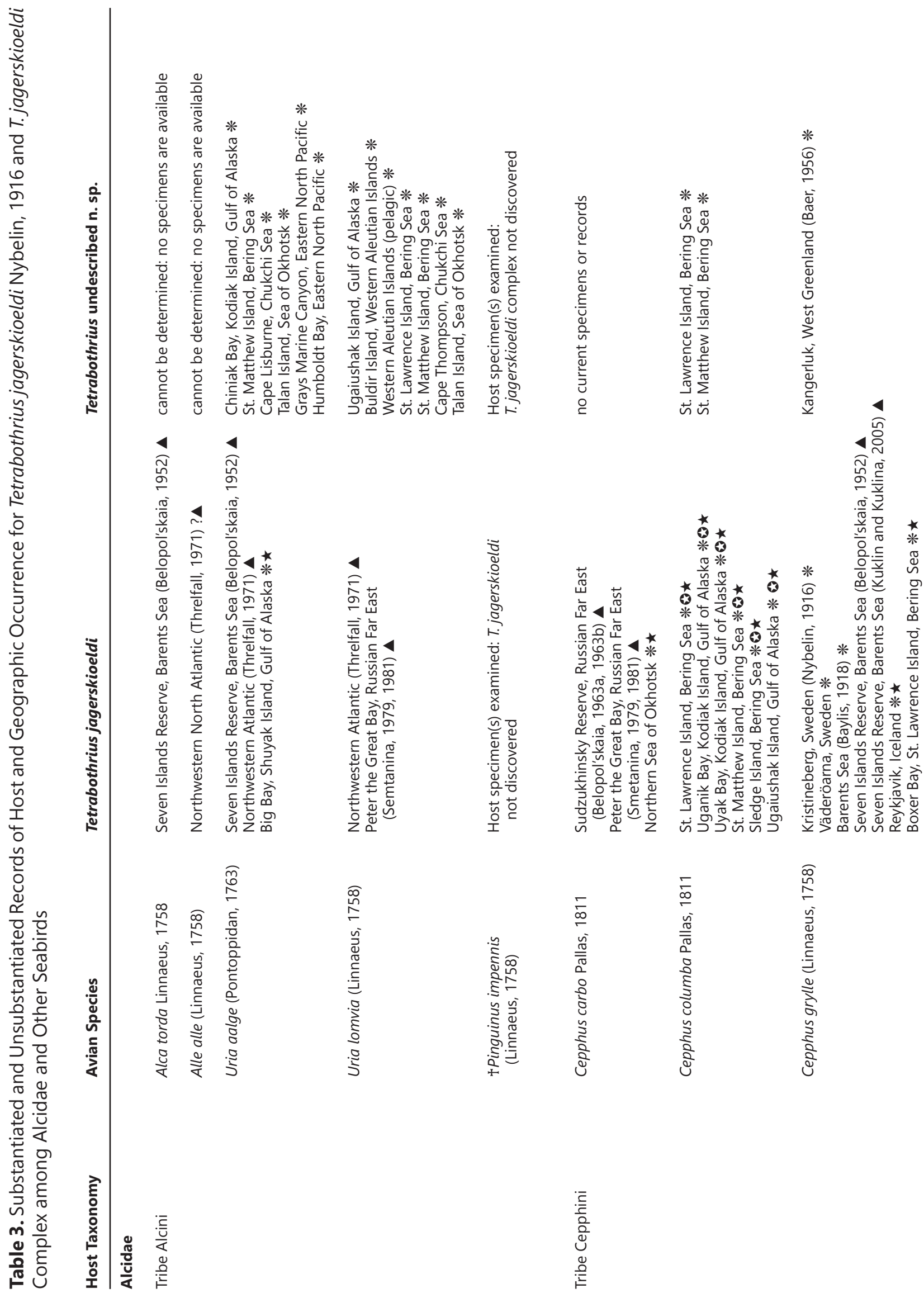




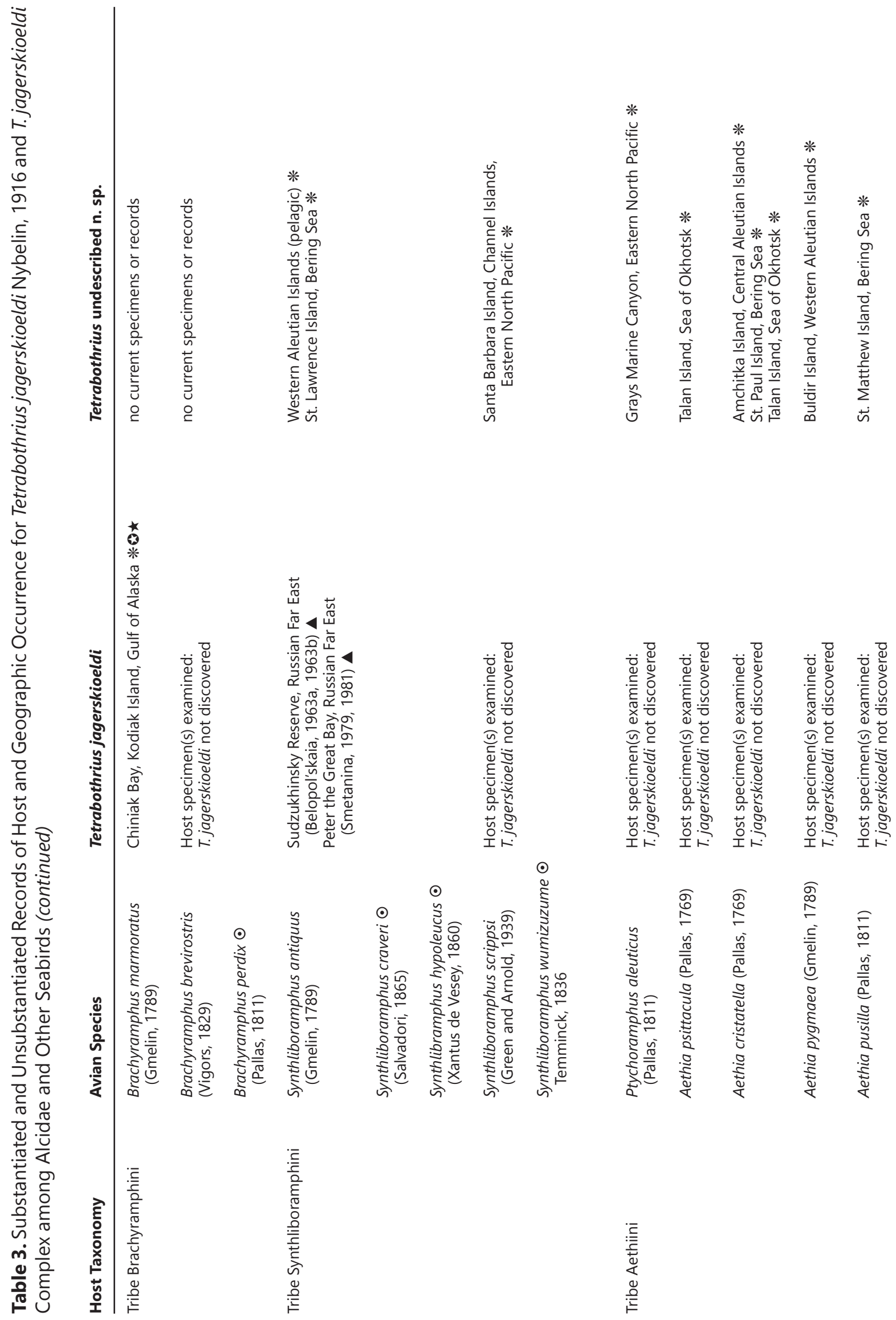




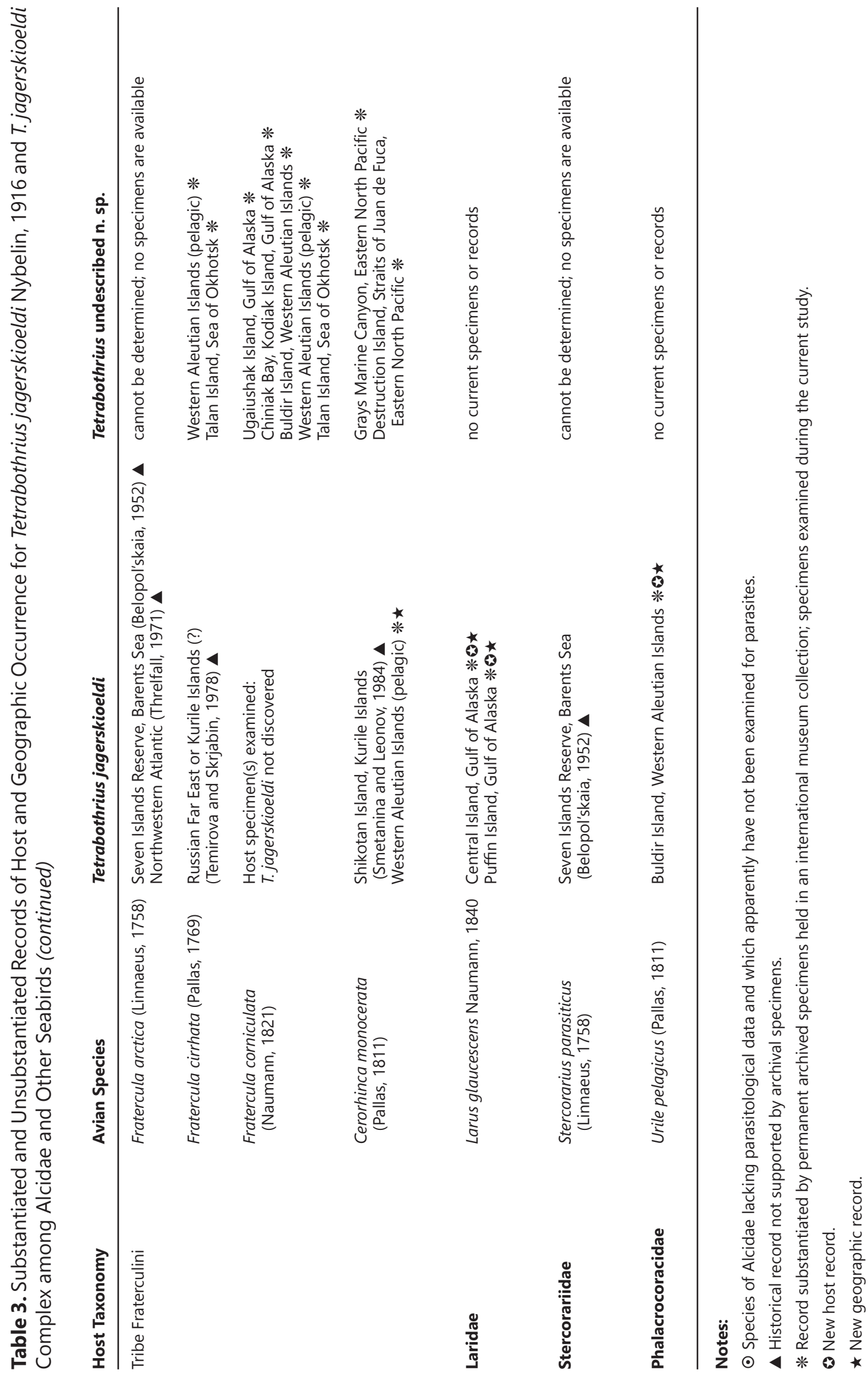


Field inventory from the North Pacific basin also revealed a putative complex of cryptic, undescribed species limited in distribution to alcid hosts. Collectively these are large strobilate tetrabothriids which share considerable superficial similarity to specimens of $T$. jagerskioeldi. These specimens, designated here as Tetrabothrius n. sp.-undescribed, represent a minimum of 4 previously unrecognized species-level taxa. Specimens of the putative complex occurred in 102 of 1,334 birds examined ( $8 \%$ prevalence) among 13 of 18 species of North Pacific Alcidae (range in intensity = 1-19) from 15 of 43 localities (Table 3; Supplementary Data Table 2); prevalence across all 1,826 specimens of seabirds sampled $=6 \%$. These putative cryptic species were not observed in other species of seabirds (larids, stercorariids, or phalacrocoracids) across the scope of collections in the North Pacific basin. Comparative morphological characterization and evaluation of this apparent cryptic assemblage as the basis for taxonomic decisions is deferred to subsequent studies among Tetrabothrius spp. in alcids that are now in progress. The nature of this assemblage could not be revealed, however, in the absence of clear morphological limits established for T. jagerskioeldi.

Specimens attributable to other nominal species of Tetrabothrius occurred in stercorariids, larids, and rarely among alcids as hosts. Multiple species of Tetrabothrius (excluding T. jagerskioeldi and Tetrabothrius n. sp.-undescribed) were found in 218 of all 1,826 avian specimens (prevalence $=12 \%$ ). Tetrabothrius spp. occurred in 26 of 1,334 alcids of 7 species (prevalence $=2 \%$ ) from 8 of 43 localities and among 192 of 439 specimens of larids and stercorariids (prevalence $=44 \%$ ) from 15 of 43 localities (Supplementary Data Table 2). Among phalacrocoracids, 53 specimens of 3 species were examined from 8 of 43 localities and none was infected with other Tetrabothrius spp. Among stercorariids, 36 specimens of 3 species were examined from 3 of 43 localities; single specimens of Tetrabothrius were found respectively in Stercorarius longicaudus Vieillot and S. pomarinus Temminck during pelagic migration during late summer to early autumn from the eastern North Pacific off the coast of Washington State. Among 403 larids examined, species of Tetrabothrius were found in 189 host specimens $(47 \%$ prevalence; range in intensity $=1-43)$ representing 7 of 10 species from 15 of 43 localities (Supplementary Data Table 2). Multiple species of Tetrabothrius and mixed infections were typical in larid hosts, and provisional assessments indicate a diverse assemblage: $T$. erostris; T. cylindraceus Rudolphi, 1819; T. cf. morschitini
Murav'eva, 1968; T. cf. macrocephalus (Rudolphi, 1808); and additional unidentified specimens (complete characterization of collections in larids and stercorariids is currently deferred).

Specimens attributable to $T$. cf. erostris were rarely observed (prevalence $<1.0 \%$ ) among alcids in the North Pacific inventory collections (Table 4; Supplementary Data Table 2); 6 of 18 alcid species were recognized as hosts. Single specimens were provisionally identified in 2 horned puffins, Fratercula corniculata (Naumann), from Buldir Island, and from pelagic habitats of the Western Aleutian Islands, 2 tufted puffins, F. cirrhata (Pallas) from Kodiak Island, a common murre, Cassin's auklet and a rhinoceros auklet from pelagic habitats over Grays Marine Canyon, Washington, and a marbled murrelet from Pt. Roberts, Washington (overall intensity $=1-18$ cestodes). Additionally, immature (usually scolex only and considerably smaller than the dimensions typical in T. jagerskioeldi) or fragmented specimens of Tetrabothrius that could not be definitively identified occurred in a spectacled guillemot, Cepphus carbo Pallas, from the northern Sea of Okhotsk, common murres from Cape Thompson (1 host) and Kodiak Island (4 hosts), a horned puffin, and 4 tufted puffins from Kodiak Island, and a single tufted puffin from Sitkalidak Island (overall range in intensity = 1-9) (Table 4; Supplemental Data Table 2). Further, as outlined above, T. jagerskioeldi was a rare component of the Tetrabothrius fauna in northern Laridae, and putative species-level taxa in the T. jagerskioeldi complex were not observed in seabird hosts beyond the Alcidae.

\section{Redescription of Tetrabothrius jagerskioeldi}

Data from the original descriptions and subsequent redescriptions of $T$. jagerskioeldi and $T$. intrepidus are summarized as a basis for comparisons. These data are augmented by new observations and series of measurements completed during the current study (Table 2; Figures 1-11). All measurements are reported in micrometers unless otherwise indicated. Mensural data are given as ranges with means in parentheses.

\section{Tetrabothrius jagerskioeldi, type series}

A partial redescription of $T$. jagerskioeldi, including new data and observations, is based on examination of the original type series of Nybelin (1916) in Cepphus grylle and other voucher specimens collected in 1916 and prepared in 1995 (Table 2); symbiotype specimens are unknown. 
Table 4. Substantiated Records of Host and Geographic Occurrence for Other Species of Tetrabothrius in Alcidae

\begin{tabular}{|c|c|c|}
\hline Parasite Species & Host Species & Geographic Distribution and Source of Record \\
\hline \multirow{2}{*}{$\begin{array}{l}\text { Tetrabothrius cylindraceus } \\
\text { Rudolphi, } 1819\end{array}$} & Uria aalge & Northwestern Atlantic (Threlfall, 1971) $\boldsymbol{\Delta}$ \\
\hline & Uria lomvia & Greenland (Ditlevsen, 1914) $\boldsymbol{\Delta}$ \\
\hline \multirow[t]{7}{*}{$\begin{array}{l}\text { Tetrabothrius erostris } \\
\text { Lönnberg, } 1896\end{array}$} & Uria aalge & $\begin{array}{l}\text { Northwestern Atlantic (Threlfall, 1971) } \\
\text { Cardignanshire, Wales } * \star \\
\text { Concarneau, France } * \star \\
\text { North Sea, Netherlands } * \star \\
\text { Grays Marine Canyon, Eastern Pacific } * \star\end{array}$ \\
\hline & Brachyramphus marmoratus & Pt. Roberts, Washington $* \star$ \\
\hline & Cepphus grylle & $\begin{array}{l}\text { Greenland (Ditlevsen, 1914) } \boldsymbol{\Delta} \\
\text { West Greenland (Baer, 1956) * }\end{array}$ \\
\hline & Cerorhinca monocerata & Grays Marine Canyon, Eastern Pacific $* \star$ \\
\hline & Fratercula cirrhata & Kodiak Island, Gulf of Alaska $* \star$ \\
\hline & Fratercula corniculata & $\begin{array}{l}\text { Buldir Island, Western Aleutian Islands } * \star \\
\text { Western Aleutian Islands, pelagic habitat } * \star\end{array}$ \\
\hline & Ptychoramphus aleuticus & Grays Marine Canyon, Eastern Pacific $* \star$ \\
\hline $\begin{array}{l}\text { Tetrabothrius macrocephalus } \\
\text { Rudolphi, } 1819\end{array}$ & Brachyramphus marmoratus & Sakhalin Island, Western North Pacific (Krotov and Deliamure, 1952) \\
\hline \multirow[t]{5}{*}{ Tetrabothrius sp. unidentified } & Uria aalge & $\begin{array}{l}\text { Northwestern Atlantic (Threlfall, 1971) } \\
\text { Cape Thompson, Chukchi Sea } * \star \\
\text { Kodiak Island Gulf of Alaska } * \star\end{array}$ \\
\hline & Uria lomvia & Northwestern Atlantic (Muzaffar, 2009) $\boldsymbol{\Delta}$ \\
\hline & Cepphus carbo & Northern Sea of Okhotsk $* \star$ \\
\hline & Fratercula cirrhata & $\begin{array}{l}\text { Kodiak Island, Gulf of Alaska } * \star \\
\text { Sitkalidak Island, Gulf of Alaska } * \star\end{array}$ \\
\hline & Fratercula corniculata & Kodiak Island, Gulf of Alaska $* \star$ \\
\hline
\end{tabular}

\section{Notes:}

$\Delta$ Record not substantiated by archived specimens.

* Record substantiated by permanent archived specimens held in an international museum collection; specimens examined during the current study.

$\star$ New geographic record.

New host record.

General redescription: Robust tetrabothriid cestodes. Total length of strobila undetermined. Craspedote, segments consistently wider than long, 420-500 × 1,4001,660 in maturity, length:width ratio 1:2.8-3.95. Scolex highly muscularized, 325 long $\times 430$ wide; with 4 prominent bothridia 285-300 long $\times 195-215$ wide; 4 auricles strongly developed. Neck region short to absent. Genital pores unilateral, dextral in dorsal view, with liplike margin at orifice. Osmoregulatory canals well developed; dorsal system 6.5-26 in diameter; ventral system 16-44, with single transverse canal, lacking multiple anastomoses. Genital ducts passing between dorsal and ventral osmoregulatory canals.
Longitudinal musculature: Musculature prominent in transverse sections of proglottids; inner and outer bundles arranged in single layers. In maturity, inner bundles large in diameter, 118-125 in number, 5-53 fibers per bundle; outer bundles relatively small in diameter; 202-221 in number; 3-12 fibers per bundle. Numbers of muscle bundles maximum in mature to gravid proglottids.

Male system: Protandrous, ontogeny of male system not determined. Testes situated in 2-3 layers, surrounding female organs, and slightly overlapping ovary along posterior margin; $(n=27$ segments, immature to early mature) 46-58 (52) in number; $(n=20) 39-78(62)$ 
1

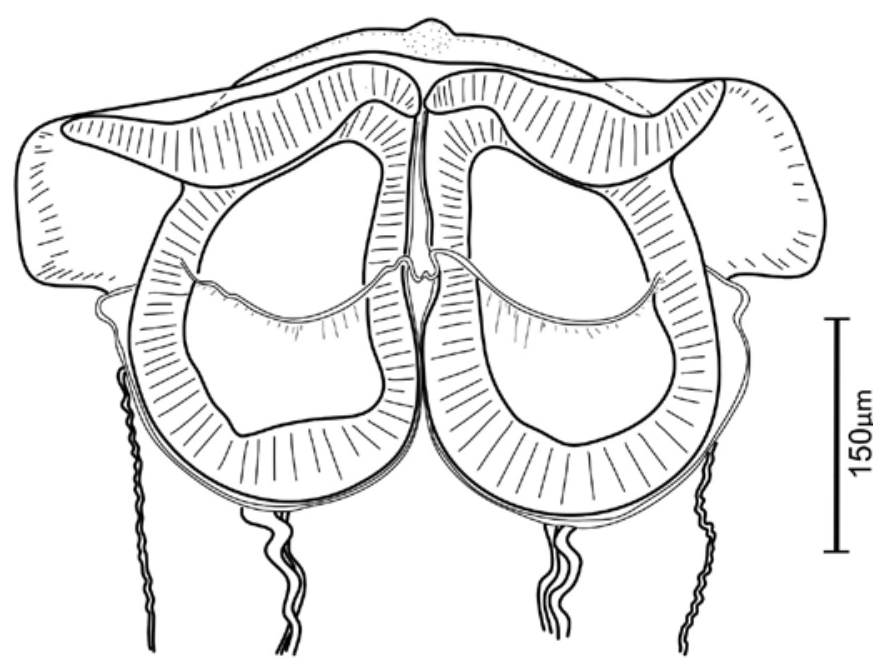

2

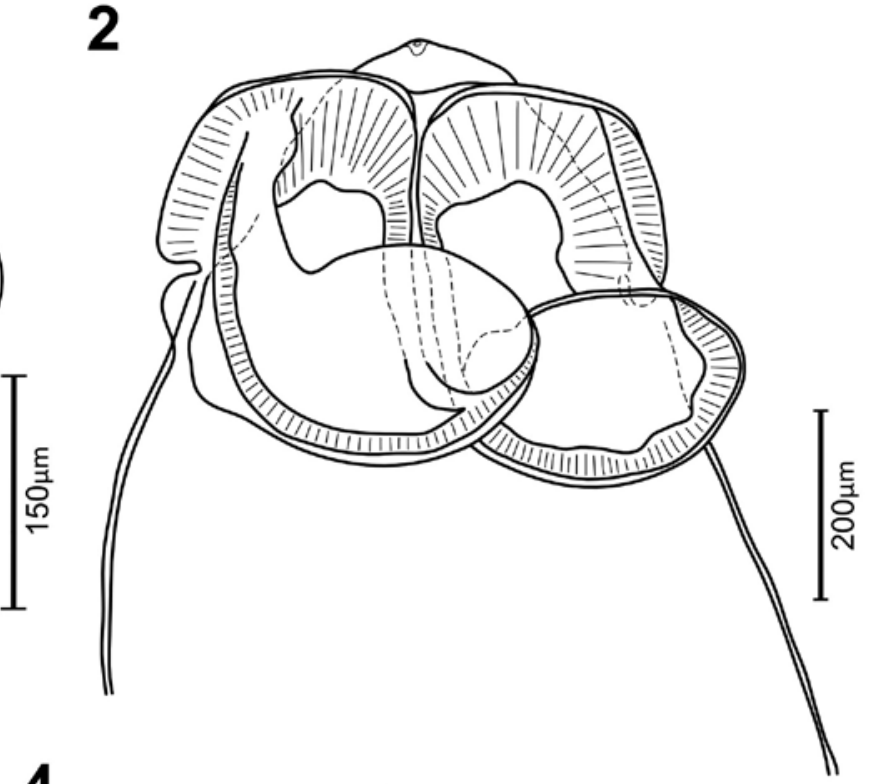

3

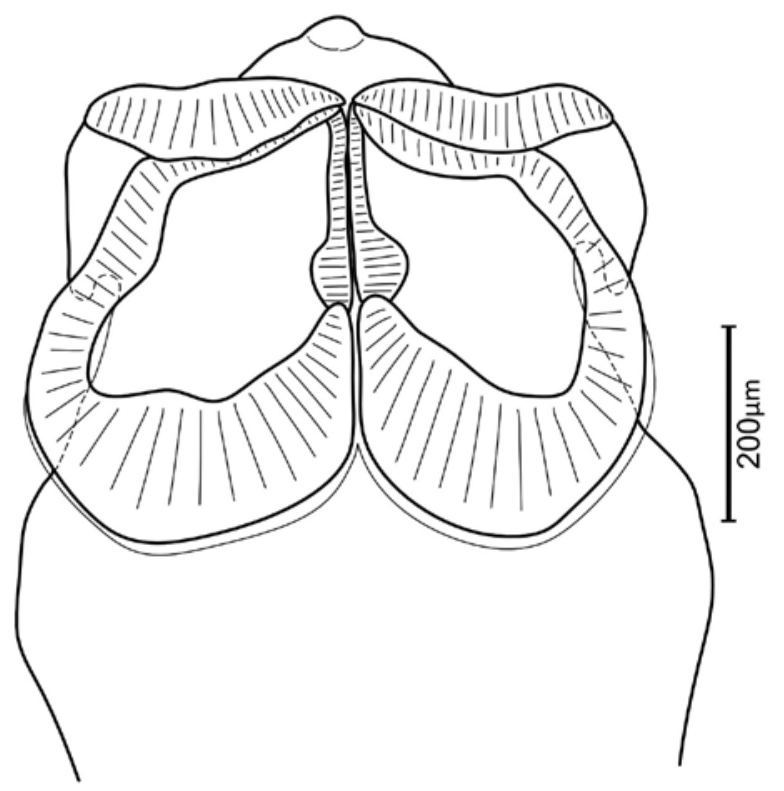

4

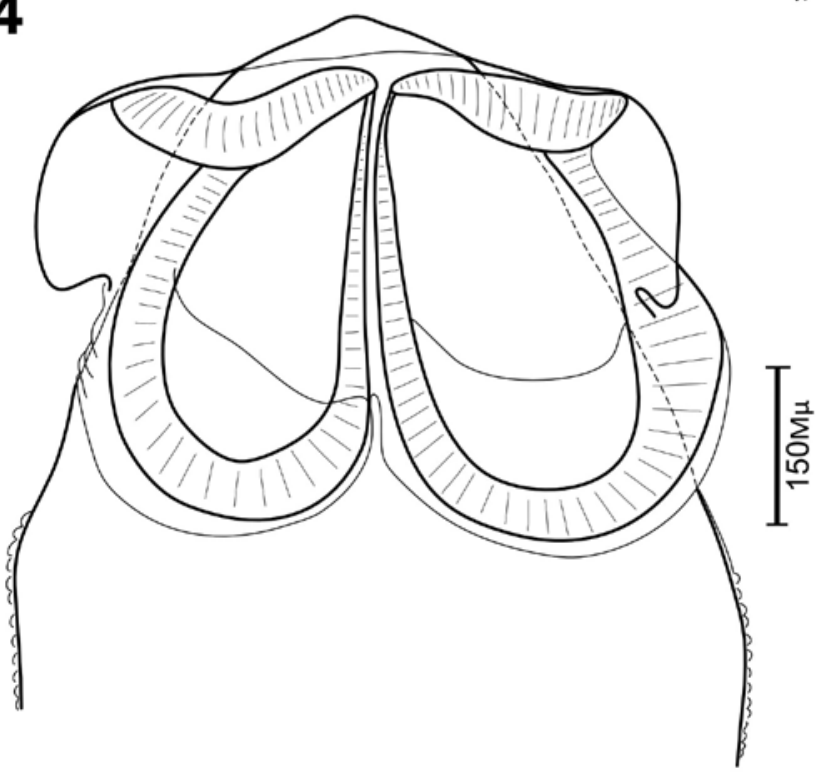

Figures 1-4. Tetrabothrius jagerskioeldi, showing structural consistency of scolex in specimens from localities and hosts across the North Atlantic and North Pacific.

Fig. 1. Specimen from voucher series of Nybelin (1916) in Cepphus grylle from Väderöarna, Sweden (Nybelin 1916-2915). Note well-developed auricular appendages and muscular bothridia. Presence of apical vestigial pedicle indicates this was a recent infection and the specimen had developed to the early mature stage.

Fig. 2. Holotype specimen of Tetrabothrius intrepidus, attributed to Baylis (1919) in Cepphus grylle from "Yukanski," Kola Peninsula, Russia (British Museum Natural History, BMNH 1919.6.14.24).

Fig. 3. Voucher specimen originally attributed to T. intrepidus in Cepphus grylle from Reykjavik, Iceland (Museum d'Histoire Naturelle, Geneva, MHN No. 65/73).

Fig. 4. Voucher specimen attributed to Tetrabothrius jagerskioeldi in Uria aalge from Shuyak Island, Alaska (R. L. Rausch Field Collection No. 13473; MSB Catalogue No. 5732). 

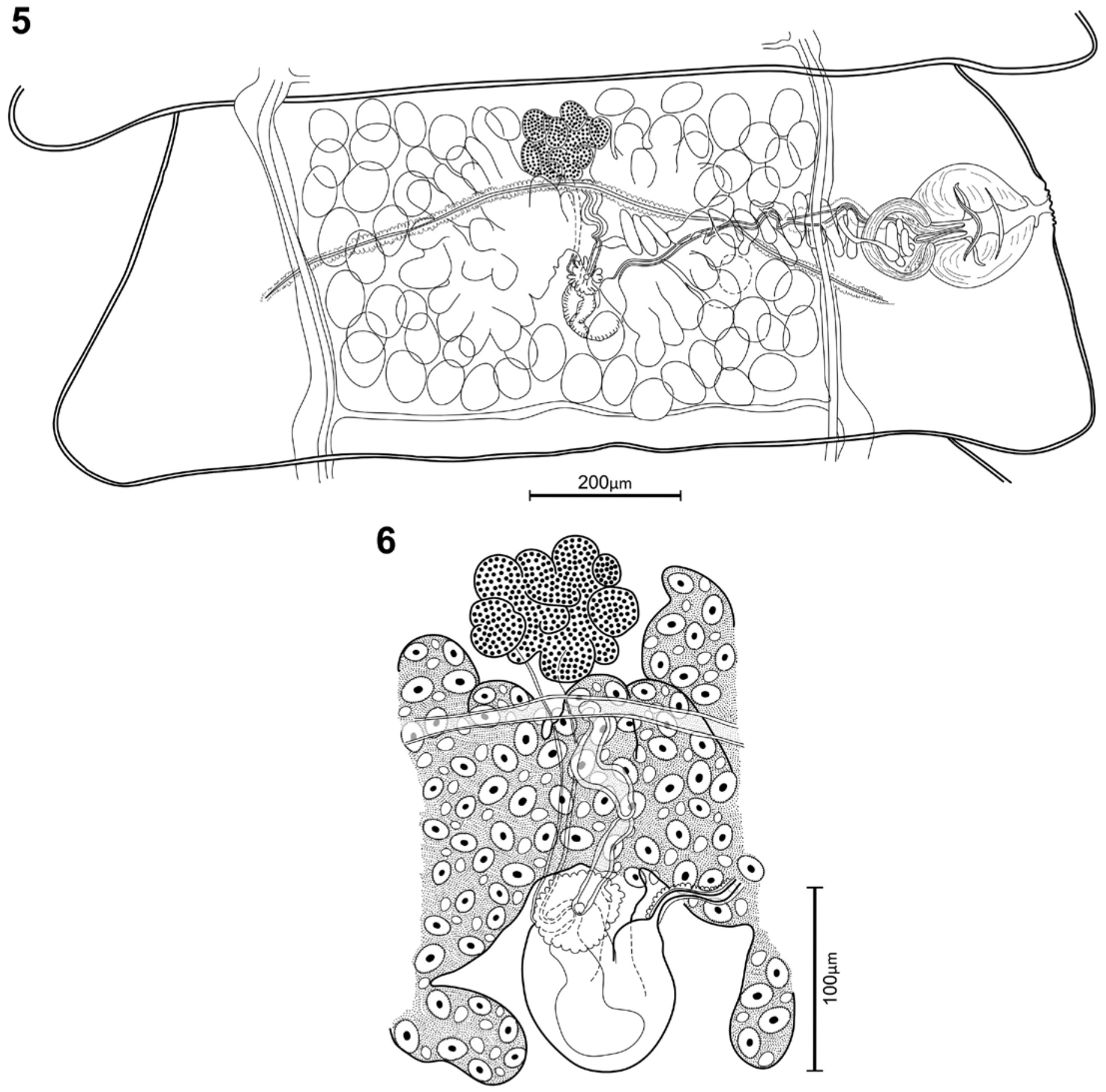

Figures 5-6. Tetrabothrius jagerskioeldi, type specimen in Cepphus grylle from Bohuslän, Kristineberg, Sweden, on 28 July 1910 (Nybelin 28-VII-1910; specimen held in Naturhistoriska Museet, Göteborg, Sweden).

Fig. 5. Mature proglottid, dorsal view in whole mount. Note dextral placement of genital pore; position of genital ducts and transverse uterine stem between osmoregulatory canals; and strongly compact, globular vitelline gland.

Fig. 6. Female genital organs and ducts in whole mount, dorsal view. Note relative positions of the ventral vitelline gland and single descending duct, posterior inner seminal receptacle ventral to the ovarian isthmus and Mehlis' gland, and the dorsal ascending uterine duct and transverse uterine stem. 

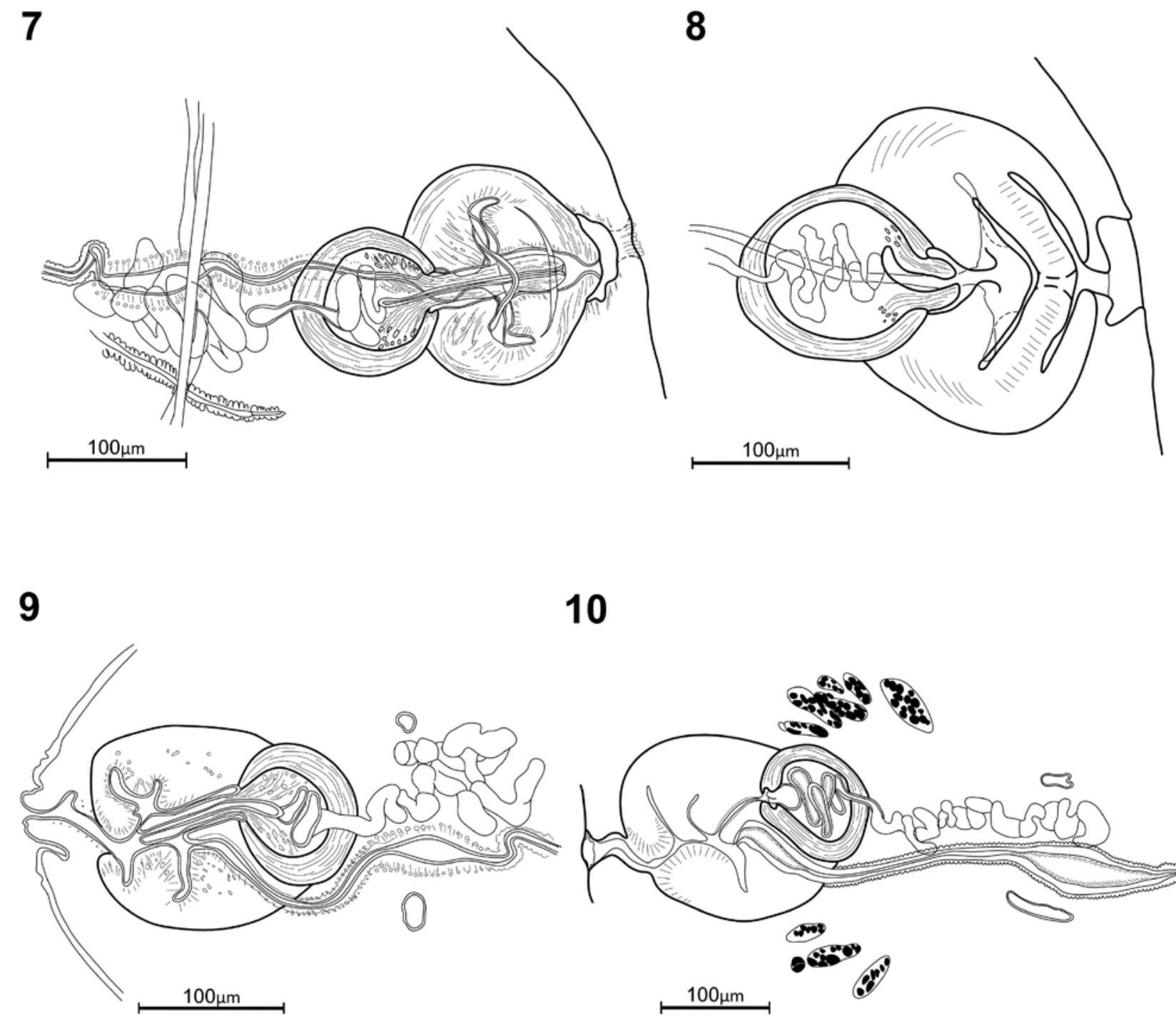

10

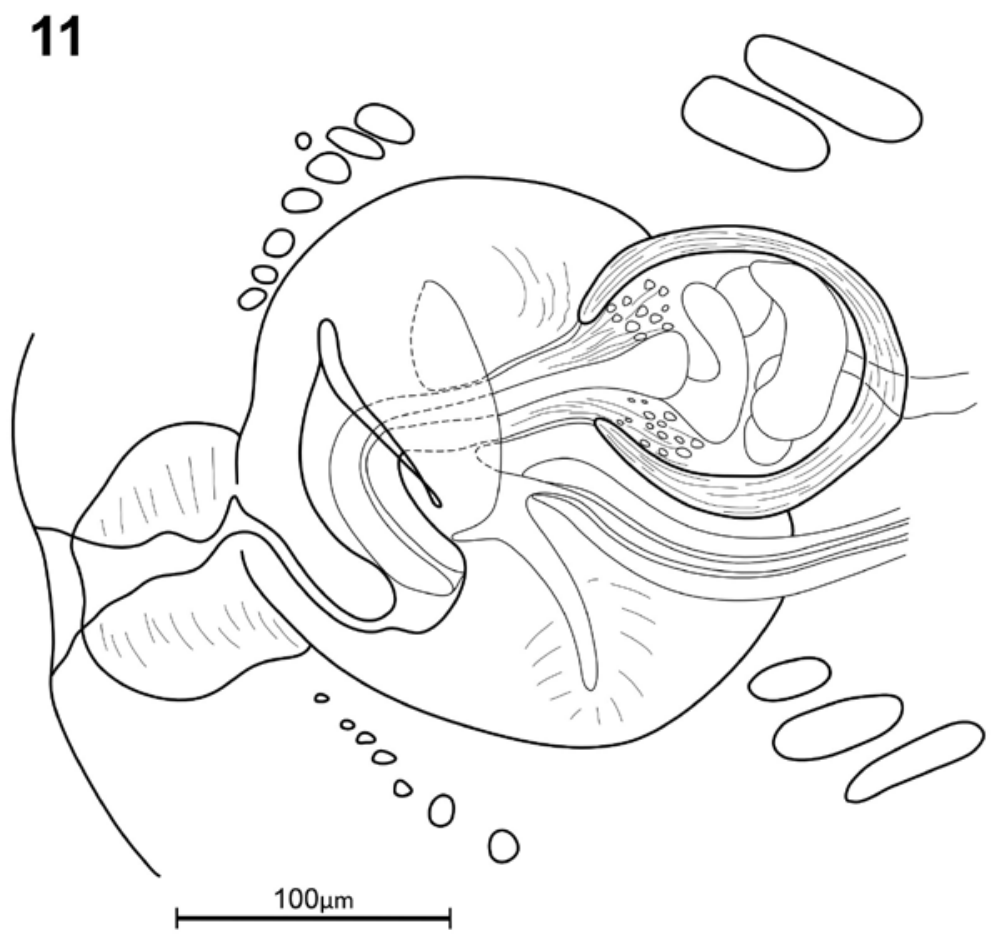


Figures 7-11. Tetrabothrius jagerskioeldi, showing structural consistency of genital atrium in lateral view from transverse sections and in whole mounts from the type series and other specimens from the North Atlantic and North Pacific.

Fig. 7. Genital atrium in dorsal view from whole mount of mature type specimen of Nybelin (1916). Note muscular genital atrium and cirrus sac, with orifice of male canal opening through prominent triangular papilla and bordered by muscular dorsal bar.

Fig. 8. Genital atrium in dorsal view from whole mount in pregravid voucher specimen attributed to T. intrepidus (Museum d'Histoire Naturelle, Geneva, MHN No. 65/72). Note prominent dorsal genital papilla and porad position of muscular dorsolateral bars.

Fig. 9. Genital atrium, lateral view from anterior, in transverse thin-section of mature type specimen of Nybelin (1916). Note muscular aspect of atrium containing relatively straight male canal with strongly muscular cirrus sac and gently curving female canal with weak dilatation distally. Genital ducts pass between the dorsal and ventral osmoregulatory canals, with spindle-shaped vaginal seminal receptacle ventral to convoluted and voluminous vas deferens.

Fig. 10. Genital atrium, lateral view from anterior in transverse, hand-cut, thick section of pregravid specimen in type series of T. intrepidus (British Museum of Natural History, BMNH 1919.6.14.24). Note position of genital atrial canals opening relative to dorsal papilla, position of dorsal bars, and distal expansion of terminal female canal. Voluminous vas deferens and spindleshaped vaginal seminal receptacle pass between the poral osmoregulatory canals. Position and structure of large inner muscle bundles in depicted.

Fig. 11. Tetrabothrius jagerskioeldi, genital atrium lateral view from anterior, in transverse, hand-cut thick section of late mature region of strobila of voucher specimen in Uria aalge from Shuyak Island, Alaska (R. L. Rausch No 13473, slide 1-B/MSB Catalog 5732). Note position of genital ducts, massive cirrus sac, and cirrus opening through prominent papilla bordered by dorso-ventrally directed muscular bars. Positions of the inner and outer muscle bundles are depicted.

in greater diameter in mature proglottids. Cirrus pouch diameter in early mature to mature $(n=25)$ 70-114 (94); in gravid ( $n=3$ ) 96-104. Vas deferens highly convoluted, voluminous. Cirrus pouch with thick wall, 16-21 in mature segments. Genital atrium diameter in early mature to mature ( $\mathrm{n}=25)$ 117-177 (140); in gravid ( $\mathrm{n}$ = 3) 153-169. Male genital canal contained within atrial wall, straight to weakly curved, opening through single, rounded, broadly triangular papilla situated in dorsal aspect of genital atrium with vaginal orifice at base; triangular structure of papilla visible in dorsal or ventral view of atrium in whole mount. Dorsal bar situated porad of male papilla in whole mount view of atrium, appearing as lateral processes extending from dorsal to ventral bordering termination of male canal in transverse thick section. Length of male canal in mature proglottids ( $n=14)$ 39-57 (46), $(n=3)$ in gravid $44-49$ as determined in transverse section.

Female system: Center of female organs primarily on midline of proglottid. Ovary bilobed, $(n=8) 410-600$ (534) wide in mature proglottids. Vitelline gland compact, globular, $(n=15)$ 101-192 (136) wide $\times 44-120$ (85) long in mature segments, situated anteroventral to ovary, with single duct extending ventral to ovary to join uterine duct in Mehlis' gland. Mehlis' gland, $(n=10) 44$ 57 (52) in diameter, on midline posterior to ovary. Inner seminal receptacle appearing as dilated region of vagina, $(n=5)$ 68-91 (81) in diameter, lateral and adjacent to Mehlis' gland. Vagina relatively straight, parallel, ventral to vas deferens. Vaginal seminal receptacle relatively small, with thickened glandular epithelium, crossing between poral osmoregulatory canals, as elongate, spindle-shaped dilatation delimited by sphincters, $(n=10)$ 52-104 (78) in length. Female canal situated ventral to male canal in genital atrium, with minimal dilatation adjacent to vaginal orifice, entering wall of genital atrium with slight curve, parallel to cirrus sac and male canal; 2 small lobes bordering vaginal aperture in dorso-ventral view. Uterus visible initially as narrow transverse tube extending dorsal to ovary, ventral to vas deferens and testes; extending between poral and antiporal osmoregulatory canals. Not dilated in maturity, expanded in pregravid condition, sacculate in gravid segments. Mature eggs obscure, dorsal uterine pore not observed.

\section{Tetrabothrius intrepidus, type series}

A partial redescription is based on examination of type specimens of T. intrepidus Baylis, 1919 in Cepphus grylle, additional specimens prepared in 1995 from the type series, and a specimen in C. grylle from Reykjavik, Iceland (Table 2); symbiotype specimens are unknown.

General: Robust tetrabothriid cestodes. Total length of strobila undetermined. Craspedote, segments consistently wider than long, 700-730 long $\times 3.5-4.0 \mathrm{~mm}$ wide in gravid strobila, length:width ratio 1:5.0-5.5. Scolex highly muscularized, 461-550 long × 597-650 wide; 
with 4 prominent bothridia $371-500$ long $\times 310-335$ wide; 4 auricles strongly developed. Apical pedicle present on scolex. Neck region short to absent. Genital pores unilateral, dextral in dorsal view, with liplike margin at orifice. Osmoregulatory canals well developed. Genital ducts passing between dorsal and ventral osmoregulatory canals.

Longitudinal musculature: Musculature prominent in transverse sections of proglottids.

Male system: Ontogeny of male system could not be determined. Number of testes not be determined. Cirrus pouch diameter in pregravid to gravid segments ( $n=17$ ) 96-130 (109). Vas deferens highly convoluted, voluminous. Cirrus pouch with thick wall, 13-26 in pregravid segments. Genital atrium diameter in pregravid to gravid segments $(n=15) 143-239$ (192); in gravid ( = 3) 153-169. Male genital canal contained within atrial wall, straight to weakly curved, opening through single, rounded, broadly triangular papilla situated in dorsal aspect of genital atrium with vaginal orifice at base. Dorsal bar situated porad of male papilla in whole mount view of atrium, appearing as lateral processes extending from dorsal to ventral bordering termination of male canal in transverse thick section. Length of male canal in pregravid proglottids ( $n=7$ ) $44-55(51)$ as determined from examination of transverse sections.

Female system: Center of female organs primarily on midline of proglottid. Ovary bilobed, becoming diffuse in pregravid proglottids. Vitelline gland compact, globular, situated anteroventral to ovary, with single duct extending ventral to ovary, $(n=3) 182-208$ wide in pregravid. Mehlis' gland on midline posterior to ovary. Inner seminal receptacle not determined. Vagina relatively straight parallel, ventral to vas deferens. Vaginal seminal receptacle relatively small, with thickened glandular epithelium, crosses between poral osmoregulatory canals, as elongate, spindle-shaped dilatation demarcated by sphincters, 117-122 in length. Female genital canal, relatively straight, disposed ventral and parallel to male genital canal in genital atrium, with minimal dilatation adjacent to vaginal orifice. Uterus saccate when gravid, extending between poral and antiporal osmoregulatory canals; dorsal uterine pore on midline at anterior margin of gravid proglottids. Eggs with irregular hyaline capsule containing embryophore $(n=20) 22-37$ (26) long $\times 30-41$ (36) wide. Oncosphere $(n=20) 18$ 23 (20) long $\times 25-33$ (30) wide; lateral embryonic hooks $(n=40)$ 12-15 (14) long; medial embryonic hooks ( $n=$ 20) $14-15$ (15) long.

\section{Tetrabothrius jagerskioeldi (North Pacific Specimens in Alcidae)}

A redescription is based on examination of 20 specimens of T. jagerskioeldi in 14 avian hosts and 6 host species among Alcidae from localities of North Pacific origin (Table 2; Supplementary Data Table 2 and Supplementary Data Table 3). Identity of these specimens was confirmed based on direct comparisons to the type series for T. jagerskioeldi.

General redescription: Large, robust tetrabothriids; maximum length of strobila $85-203 \mathrm{~mm}$. Segments wider than long throughout strobila; $(n=19) 275-675$ $(445) \times 1,625-3,125(2,172)$ in mature; $(n=12) 375-775$ $(550) \times 1,825-3,375(2,566)$ in pregravid; maximum observed $(n=13) 525-1,075(747) \times 2,230-3,900(2,784)$ in gravid. Length:width ratio in mature 1:4.9-5.1; in pregravid, 1:4.96-5.09; in gravid 1:2.44-4.73. Scolex rectangular, wider than long $(n=16) 350-580$ (489) long $\times$ 490-700 (580) wide; auricles prominent. Bothridia well developed, $(n=24)$ 240-500 (406) long $\times 235-370$ (277) wide, with muscular margins. Apical region with slight rounded expansion; often with vestigial pedicle of apical sucker. Neck relatively short. Ventral osmoregulatory canals large in diameter; single transverse canal without anastomoses; dorsal canals narrow. Genital pores unilateral, dextral, situated marginally in middle third of proglottid. Genital ducts and extensions of transverse uterus pass between poral osmoregulatory canals.

Longitudinal musculature: Musculature prominent in transverse sections of proglottids; inner and outer bundles arranged in single layers. Inner bundles large in diameter; $(n=8)$ 99-146 (114) in number; $(n=20) 6-37$ (19) fibers per bundle. Outer bundles relatively small in diameter; $(n=8) 185-237$ (204) in number; $(n=20)$ 3-11 (7.0) fibers per bundle. Numbers of muscle bundles maximum in mature proglottids, diminishing in number posteriad in post-mature and gravid segments.

Male system: Genital anlagen visible immediately posterior to neck. Testes positioned dorsally in 2-3 layers surrounding and partially overlapping female organs. Testes ( $n=54$ segments from 7 strobila) 40-70 (54) in number counted in immature to early mature segments. Vas deferens prominent, highly convoluted, distended adjacent to poral osmoregulatory canals. Cirrus sac ovoid, situated in dorsal aspect of genital atrium, increasing in diameter posteriad, attaining maximum dimensions in gravid segments; diameter $(n=111) 65$ 110 (88) in mature, $(n=109) 75-130(93)$ in pregravid, $(n=44)$ 78-152 (106) in gravid. Cirrus sac with thickened muscular wall $15-25$. Cirrus sac contains extension 
of convoluted vas deferens and cirrus armed with miniscule but prominent spines. Genital atrium ovoid, structurally consistent with Nybelin and Baylis type series, highly muscularized, attaining maximum dimensions in gravid segments; $(n=47) 125-190(154)$ in mature, $(n=$ 55) $112-230$ (169) in pregravid, $(n=20) 142-205$ (177) in gravid. Male genital canal, dorsal, extending through wall of atrium, straight to weakly curved ventrally, opening on ventral aspect of prominent triangular male papilla in center of atrial lumen; sphincters not observed. Length of male canal increases with age of proglottid and development of genital atrium; $(n=10) 41-50$ (45) long in maturity; $(n=48) 37-62(47)$ in late mature to pregravid segments.

Female system: Ovary multilobate, with 2 prominent wings, situated in anterior $2 / 3$ of segment with center of female organs on midline; not extending to osmoregulatory canals; $(n=58) 450-980(689)$ in maximum width in mature segments, $(n=20) 420-900(708)$ in pregravid. Vitelline gland, compact, globular, $(n=60)$ 120-400 (202) wide $\times$ 48-170 (108) long in mature, $(n=$ 25) 120-280 (208) × 70-140 (105) in pregravid; situated anteroventral to ovary, with center of organ on midline; with single broad common vitelline duct passing ventral to ovary. Common vitelline duct extends posteriad to join uterine duct enclosed within Mehlis' gland ventral to ovary. Vagina terminates proximally as thin-walled, ellipsoidal inner seminal receptacle; extends porad as thin tube ventral to testes, dorsal to ovary. Vaginal seminal receptacle present as elongate, spindle-shaped dilatation, demarcated by sphincters at the level of the poral osmoregulatory system; maximum length $(n=10) 100$ 157 (132) in mature, $(n=20) 100-170(127)$ in pregravid segments, attained adjacent to but not overlapping poral wing of ovary. Distal vagina with thickened muscular wall, enters genital atrium ventral to cirrus sac, parallel to male genital canal, opening ventrally near base of male papilla; region of distal vagina within atrial wall minimally expanded as atrial seminal receptacle; atrial vagina spinose. Ascending uterine stem extends anteriad from dorsal aspect of Mehlis' gland; transverse tubular uterine stem initially visible coinciding with ovarian development. Mature uterus, a broad sacculate structure lined with cellular epithelium, situated dorsally in proglottid, extending between osmoregulatory canals. Uterine pore median, dorsal, patent in pregravid strobila; segments anapolytic. Mature eggs contained within capsule and granular membrane $(n=10) 65-82.5(73)$ in diameter. Hyaline embryophore $(n=10) 27.5-35$ (29.5) long $\times(n$ $=21$ ) 34-42.5 (39) wide; containing oncosphere $(n=40)$
20-26 (23) long $\times$ 27.5-39 (32) wide. Embryonic hooks similar in structure and dimensions, $(\mathrm{n}=17) 12.5-17.5$ (15) long for medial pairs, $(n=19) 15-17.5$ (15.5) for lateral groups.

Host Species: Brachyramphus marmoratus (Gmelin), Cepphus carbo Pallas, Cepphus columba Pallas, Cepphus grylle (Linnaeus), Cerorhinca monocerata (Pallas), Uria aalge (Pontoppidan).

Voucher Specimens in Alcidae, North Pacific Basin: Museum of Southwestern Biology, Parasitology Division-MSB PARA-1738, 3990, 4046, 5732, 26828, 27879, 27880, 27912, 27916, 27919, 27927, 27928, 29234, 28951. (See Table 2 and Table 3 including new data for host and geographic distributions; Supplementary Data Table 2; Supplementary Data Table 3).

Symbiotype Specimens: Unknown.

\section{Tetrabothrius jagerskioeldi (North Pacific Specimens in Laridae and Phalacrocoracidae)}

A partial redescription is based on examination of 29 specimens of $T$. jagerskioeldi in 14 individuals of Larus glaucescens hosts and 1 specimen in Urile pelagicus from North Pacific localities (Table 2; Supplementary Data Table 2 and Supplementary Data Table 3). Identity of these specimens was confirmed based on direct comparisons to the type series and to specimens recovered in Alcidae hosts from the North Pacific Basin.

General redescription: Large, robust tetrabothriids; maximum length of strobila 101-158. Segments wider than long throughout strobila; $(n=4)$, width 1,618-3,348 $(2,497)$ in mature; $(n=4) 2,560-3,710$ in pregravid; maximum observed $(n=11) 2,817-4,540(3,645)$ in gravid. Scolex rectangular, wider than long $(n=25) 393-632$ (512) long $\times$ 477-786 wide; auricles prominent. Bothridia well developed. Apical region with slight rounded expansion; often with vestigial pedicle of apical sucker. Neck relatively short. Ventral osmoregulatory canals large in diameter; single transverse canal without anastomoses; dorsal canals narrow. Genital pores unilateral, dextral, situated marginally in middle third of proglottid. Genital ducts and extensions of transverse uterus pass between poral osmoregulatory canals.

Longitudinal musculature: Prominent in transverse sections of proglottids; inner and outer bundles arranged in single layers. Inner bundles large in diameter; ( $n=14$ ) 60-104 (84) in number. Outer bundles relatively small in diameter; $(n=14)$ 143-184 (172) in number.

Male system: Genital anlagen visible immediately posterior to neck. Testes positioned dorsally in 2-3 layers surrounding and partially overlapping female organs. 
Testes ( $\mathrm{n}=174$ segments from 21 strobila) 40-73 (55) in number counted in immature to early mature segments. Vas deferens prominent, highly convoluted, distended adjacent to poral osmoregulatory canals. Cirrus sac ovoid, situated in dorsal aspect of genital atrium, increasing in diameter posteriad, attaining maximum dimensions in gravid segments; diameter $(n=345) 60$ 119 (91) in mature, $(n=181)$ 88-126 (107) in pregravid, $(n=68) 91-132$ (110) in gravid. Cirrus sac with thickened muscular wall. Cirrus sac contains extension of convoluted vas deferens and cirrus armed with miniscule but prominent spines. Genital atrium ovoid, structurally consistent with Nybelin and Baylis type series, highly muscularized, attaining maximum dimensions in gravid segments; $(n=79)$ 95-203 (159) in mature, $(n=43) 155$ 238 (194) in pregravid, $(n=20)$ 145-215 (175) in gravid. Male genital canal, dorsal, extending through wall of atrium, straight to weakly curved ventrally, opening on ventral aspect of prominent triangular male papilla in center of atrial lumen; sphincters not observed. Length of male genital canal showing limited variation with age of proglottid and development of genital atrium; ( $n=$ 55) 36-65 (52) long in maturity; $(n=27) 34-60$ (52) in late mature to pregravid segments.

Female system: Ovary multilobate, with 2 prominent wings, situated in anterior $2 / 3$ of segment with center of female organs on midline; not extending to osmoregulatory canals; $(n=69) 560-1,251$ (810) in maximum width in mature segments; $(n=37) 838-1,335(1,110)$ in pregravid. Vitelline gland, compact, globular, $(n=100) 107-$ 345 (198) wide $\times 52-155$ (107) long in mature, $(n=53)$ 179-370 (284) wide in pregravid; situated anteroventral to ovary, with center of organ on midline; with single broad common vitelline duct passing ventral to ovary. Common vitelline duct extends posteriad to join uterine duct enclosed within Mehlis' gland ventral to ovary. Vagina terminates proximally as thin-walled, ellipsoidal inner seminal receptacle; extends porad as thin tube ventral to testes, dorsal to ovary. Vaginal seminal receptacle present as elongate, spindle-shaped dilatation, demarcated by sphincters at the level of the poral osmoregulatory system. Distal vagina with thickened muscular wall, enters genital atrium ventral to cirrus sac, parallel to male genital canal, opening ventrally near base of male papilla; region of distal vagina within atrial wall minimally expanded as atrial seminal receptacle; atrial vagina spinose. Ascending uterine stem extends anteriad from dorsal aspect of Mehlis' gland; transverse tubular uterine stem initially visible coinciding with ovarian development. Mature uterus, a broad sacculate structure lined with cellular epithelium, situated dorsally in proglottid, extending ventrally beyond and between poral and antiporal osmoregulatory canals. Uterine pore median, dorsal, patent in pregravid strobila; segments anapolytic. Mature eggs contained within capsule and granular membrane. Hyaline embryophore containing oncosphere $(n=64) \times 21-31$ long $\times(n=83) 29-44(36)$ wide. Embryonic hooks similar in structure and dimensions, $(n=39)$ 12.5-18 (15.5) long for medial pairs, $(n=$ 39) 12.5-18 (16) for lateral groups.

Host Species: Larus glaucescens (Naumann), Urile pelagicus (Pallas).

Voucher Specimens in Laridae and Phalacrocoracidae, North Pacific Basin: Museum of Southwestern Biology, Parasitology Division-MSB PARA—27910, 27871, 27872, 27873, 27874, 27875, 27876, 27883, 27886, 27890, 27894, 27898, 27902, 27905, 27908. (See Table 2 and Table 3 including new data for host and geographic distributions; Supplementary Data Table 2, Supplementary Data Table 3).

Symbiotype Specimens: Unknown.

\section{Remarks-Defining Morphological and Species Diversity}

Specimens of T. jagerskioeldi are diagnosed by a characteristic configuration of the genital atrium, position of the male and female genital canals, structure of the male and female organ systems, and numbers of testes (Figures 1-11; Table 2). The marginal genital atrium, dextral in position, and observed in dorso-ventral view, is defined by a prominent, dorsally situated, triangular papilla with the aperture of the male canal opening centrally near the base and female canal adjacent and ventral in position. In transverse section, lateral processes extend ventrally from the dorsal aspect of the genital atrium bordering the anterior edge of male genital papilla. The vagina is relatively straight entering the wall of the genital atrium and slightly curved in parallel to the cirrus sac and male canal. The genital ducts and transverse uterine stem pass between the poral osmoregulatory canals; the uterine stem passes between the antiporal canals. The transverse ventral osmoregulatory canal lacks multiple anastomoses. The vaginal seminal receptacle occurs as a spindle-shaped expansion with a prominent epithelium, demarcated by sphincters, at the level of the poral canals. The center of the female organ system (vitelline gland and bi-winged, multilobate ovary, Mehlis' gland) is aligned with the midline of the proglottid. The vitelline gland is strongly compact, globular, and with a 
single descending duct. Testes only exceptionally exceed 60 in number; maximum observed in confirmed specimens $=70-73$, minimum $=40 ;$ mean number in specimens from alcids or larids is about 55 .

A suite of characters from original descriptions (and new specimen-based observations from the type series) of $T$. jagerskioeldi and the junior synonym $T$. intrepidus consistently establish identity (Nybelin, 1916; Baylis, 1919). Morphologically, specimens examined from the North Pacific inventory are structurally indistinguishable from the type series, particularly with respect to the configuration of the genital atrium (Figures 1-11; Table 2). The genital atrium remains among the most diagnostically important characters for identification across genera and species of Tetrabothriidae. Defining the limits for structural and meristic characters within species requires a series of measurements and observations that account for ontogeny of male and female genital systems with respect to progressive development of the strobila (Murav'eva and Popov, 1976; Hoberg, 1987; Hoberg et al., 1991).

An understanding of the morphological limits for $T$. jagerskioeldi derived from a large series of geographically disparate specimens has direct implications for documenting parasite diversity. Correct identification of all cestodes included in redescriptions outlined in monographs by Baer (1954) and Temirova and Skrjabin (1978) may be equivocal, as specimens are no longer available for verification, and detailed data for field collections were not generally presented (Table 2). Considering meristic data in these monographs, it is apparent that some, but not all, specimens would have represented T. jagerskioeldi. Figures of the genital atrium presented for T. jagerskioeldi by Baer (1954) at a minimum indicate some component of Nybelin's mounted histological sections and type specimens had been evaluated. It is not clear, however, that other specimens were examined from a broader range of alcid hosts (Alca torda and Uria aalge) that were reported in the monograph. Thus, later misidentification of $T$. jagerskioeldi from localities in West Greenland is problematic. Baer (1956) reported this species in Alca torda (specimens consistent with $T$. erostris) and Cepphus grylle (consistent with an undescribed species), and this is a case in which identity of voucher specimens held in Museum d'Histoire Naturelle, Geneva, could be verified.

Temirova and Skrjabin (1978) examined, redescribed, and completed a series of figures attributed to T. jagerskioeldi from specimens likely to have been originally collected by Belopol'skaia (1952) from the Seven
Islands Reserve in Arctic Russia. Included were specimens in parasitic jaeger, Stercorarius parasiticus (Linnaeus), and cestodes in Cepphus grylle, Alca torda, and Fratercula arctica (Linnaeus). As depicted in a series of published figures, the presence of a massive domelike apical expansion of the scolex, apparent ventral position of the genital ducts, relative width of the vitelline gland (elongate), and the large diameter of the genital atrium in at least some of these specimens are inconsistent with the Göteborg type series and North Pacific specimens of $T$. jagerskioeldi. We suggest that the redescription outlined by Temirova and Skrjabin (1978) is a composite, which includes $T$. jagerskioeldi and at least one currently undescribed species of Tetrabothrius. Our contention, however, cannot be directly evaluated as the collections assembled by Belopol'skaia (1952) were accidentally destroyed.

The identity of $T$. jagerskioeldi and consequently the published host ranges remain problematic and, in some cases, unsubstantiated as a considerable number of records based on field collections can no longer be linked directly to specimens (e.g., Ditlevsen, 1914; Krotov and Deliamure, 1952; Belopol'skaia, 1952, 1963a, 1963b; Threlfall, 1971; Smetanina, 1979, 1981; Temirova and Skrjabin, 1978; Smetanina and Leonov, 1984) (Table 3). The documentation of host occurrence was seldom validated through identified parasite specimens that were archived. Host and geographic distributions are further confounded now by a cryptic complex of species that is recognized in our current study of available specimens (Table 3; Supplementary Table 2).

\section{Defining a Species Complex in T. jagerskioeldi}

Based on the spectrum of characters we explored, it was apparent that numerous specimens of Tetrabothrius among genera and species of Alcidae from the North Pacific inventory could not be accommodated in T. jagerskioeldi (Table 3; Table 5; Supplementary Data Table 2). Superficially, these are all large and robust tapeworms referable to Tetrabothrius, potentially contributing to misidentifications and misattribution that have occurred both in the literature and in the few archived specimens in museums (BMNH and $\mathrm{MHN}$ ) as revealed in our current study. An array of qualitative (structural) and quantitative attributes partitioned among these specimens are discordant with $T$. jagerskioeldi but concurrently exhibit considerable stability with respect to geographic and host distributions (Table 3; Table 5). A complex of otherwise cryptic and undescribed species minimally involving 
Table 5. Characters That Are Discordant with Tetrabothrius jagerskioeldi Nybelin, 1916

- Scolex structure and dimensions

- Structure of the osmoregulatory canals

- Structure of genital atrium, including papilla(e), position, direction and length of the male and female canals, dilatations of the atrial vagina

- Structure and position of the distal vagina near junction with genital atrium

- Structure and dimensions of the vitelline gland; structure of descending vitelline duct(s)

- Position of genital ducts and transverse uterine stem relative to osmoregulatory canals

- Structure and position of the vaginal seminal receptacle

- Position of female organs relative to the midline of the proglottid

- Position of the genital pore

- Numbers of testes

3-4 additional taxa contained within T. jagerskioeldi is indicated (Table 3; Supplementary Data Table 2); these are designated a Tetrabothrius undescribed n. sp. in our current study. The details and taxonomic decisions that will emerge from these observations are deferred for ongoing studies defining diversity in the marine fauna. Some salient points, however, regarding recognition of a species complex are outlined in the subsequent section.

\section{Discussion}

Hoberg (1984) and Muzaffar and Jones (2004) summarized data for diversity of helminths including species of Tetrabothrius among Alcidae derived from the published record outlined in the literature. Both reviews were based on assumptions of a single species of large, robust tapeworm, namely $T$. jagerskioeldi, as the predominant representative of Tetrabothrius in alcid hosts. Hoberg (1984) did not provide species-level identification for specimens in alcids from the North Pacific at that time; those collections are now under evaluation in our current study.

Historically Tetrabothrius jagerskioeldi has been considered a typical or characteristic parasite across a broad diversity of seabirds among the Alcidae
(Charadriiformes) (e.g., Fuhrmann, 1932; Joyeaux and Baer, 1936; Belopol'skaia, 1952; Baer, 1954; Yamaguti, 1959; Temirova and Skrjabin, 1978; Schmidt, 1986; Mariaux et al., 2017). Records from hosts beyond the Alcidae have not been reported except for those in parasitic jaegers from the Seven Islands Reserve by Belopol'skaia (1952), and specimens in glaucouswinged gulls and a pelagic cormorant in our study. None of these definitive monographs have a foundation established by the deposition of archival vouchers in various international collections. Other species, including T. cylindraceus, T. erostris, and T. macrocephalus have sporadically been reported in alcids (Temirova and Skrjabin, 1978; see reviews in Hoberg, 1984; Muzaffar and Jones, 2004) (Table 4). These are readily distinguished from T. jagerskioeldi based on the dimensions of the scolex, numbers of testes, and specific attributes of the genital atrium and cirrus sac (e.g., Baer, 1954; Temirova and Skrjabin, 1978). Reports of occurrence and distribution over the past century (now including original records and corrections outlined in our study) recognize 4 nominal species of Tetrabothrius in as many as 14 host species among the 24 extant Alcidae (Table 3, Table 4); 6 alcid host species are validated for T. jagerskioeldi by archived voucher specimens in our study (Table 3; Supplementary Data Table 2). Further, 14 alcid species are identified as hosts for an assemblage of 3-4 cryptic and currently undescribed species constituting a complex within T. jagerskioeldi.

A clear definition of $T$. jagerskioeldi derived from our current evaluations and the recognition of an apparent complex of species (Table 3; Supplementary Data Table 2) brings to question the reliability of identifications that have been outlined in the literature. The absence of archived voucher specimens further renders it impossible to adequately evaluate almost all prior reports that otherwise would document the host range and geographic distribution of $T$. jagerskioeldi and other species of Tetrabothrius. Some records, linked to redescriptions, may be correct as outlined in Table 2, but there is now no mechanism for assessing their validity. It is important to note that in instances for which vouchers had been archived for putative specimens of T. jagerskioeldi or T. intrepidus, many of those identifications have been shown to be incorrect (e.g., Baer (1956)—specimens in Alca torda and Cepphus grylle from West Greenland and archived museum specimens in $U$. aalge from France, the Netherlands, and Wales). 


\section{Exploring Host Range for T. jagerskioeldi and Tetrabothrius spp.-The North Pacific Inventory}

Inventory from localities spanning the North Pacific during a 40-year period from the early 1950 s to the early 1990s, as outlined in our study, constitutes the first geographically extensive, specimen-based, and archived collections to serve as a foundation and baseline for exploring species diversity and distribution (Supplementary Data Table 2). Specimens attributed to T. jagerskioeldi from these field collections were morphologically consistent with those examined in the type series from Sweden (Table 2). We confirm six alcid species (U. aalge, $C$. carbo, C. columba Pallas, C. grylle, B. marmoratus (Gmelin), C. monocerata (Pallas)), a larid (L. glaucescens), and a phalacrocoracid (U. pelagicus) as hosts encompassing a widespread oceanographic range across the North Pacific basin (Table 3; Supplementary Data Table 2). Although a broad host range is apparent, most validated records are now associated with guillemots, species of Cepphus, from the Holarctic.

Specimens of $T$. jagerskioeldi were also recovered from hosts among the Laridae and Phalacrocoracidae during geographically extensive surveys at localities in the North Pacific basin (Hoberg, 1979, 1992; E. P. Hoberg, unpublished data; Supplementary Data Table 2). Morphologically based identification was confirmed for a series of specimens in a pelagic cormorant (Buldir Island) and in glaucous-winged gulls, Larus glaucescens. Gulls were collected near Central Island (adjacent to Ugaiushak Island) along the Alaska Peninsula during 1976 (4 of 20 adult gulls examined) and at Puffin Island in Chiniak Bay, Kodiak Island during 1977 (10 of 31 adults examined), both sites in the northern Gulf of Alaska. Overall, $21 \%$ of glaucous-winged gulls examined at these 2 localities were infected with specimens attributable to T. jagerskioeldi; specimens were not found in 13 glaucous-winged gulls examined at Amchitka Island in the central Aleutian Islands in 1976. Mixed species infections in glaucous-winged gulls, involving T. jagerskioeldi, $T$. cf. cylindraceus, and $T$. cf. erostris and possibly undescribed species of Tetrabothrius occurred at these sites in the Gulf of Alaska. Overall prevalence for all species of Tetrabothrius at Central Island and at Puffin Island were $100 \%$ and $88 \%$ respectively, indicating the tetrabothriid fauna among larids at these localities was dominated by species other than T. jagerskioeldi.

Additional specimens once considered to represent $T$. jagerskioeldi among alcids are now partitioned among an assemblage of previously unrecognized species, collectively designated here as Tetrabothrius undescribed n. sp. Prior to detailed comparative morphological evaluations initiated during our study (and in progress), these series of specimens had been provisionally referred to T. jagerskioeldi (Hoberg, 1984; Table 3; Supplementary Data Table 2) and in part to Tetrabothrius spp. (e.g., Muzaffar and Jones, 2004). Specimens, including those from the North Pacific inventory and Greenland (Baer, 1956), are partitioned to some degree among 14 species of alcids: Alcini (U. aalge and U. lomvia (Linnaeus)), Cepphini (C. grylle and C. columba), Synthliboramphini (S. antiquus (Gmelin), S. scrippsi (Green and Arnold)), Aethiinae (A. cristatella (Pallas), A. pusilla (Pallas), A. pygmaea (Gmelin), A. psittacula (Pallas), P. aleuticus (Brandt)), and Fraterculini (F. corniculata, F. cirrhata, C. monocerata). Typically, these were large and robust cestodes, superficially resembling T. jagerskioeldi. A cryptic complex with distinct species distinguished by, among other characters, the numbers of testes, attributes of the genital atrium, structure of the genital papilla, position of the genital pore, structure of the vaginal seminal receptacle, and placement of the male and female canals can be defined (Table 5). Historically, the morphological limits for T. jagerskioeldi had not been adequately delineated, leading to confusion about the diversity of cestodes that may occur among genera and species of alcids and other marine birds. Host and geographic range for an assemblage of species will be explored in subsequent taxonomic studies and descriptions of the T. jagerskioeldi species complex.

Considering a broader faunal assemblage circulating among seabirds, tapeworms consistent with T. jagerskioeldi or Tetrabothrius undescribed n. sp. were not observed among 477 avian specimens (larids, stercorariids, phalacrocoracids, excluding 14 L. glaucescens and 1 U. pelagicus) of 13 species from North Pacific collections (Supplementary Data Table 2). Notably sampling involved 165 specimens of the pelagic foraging blacklegged kittiwake (Rissa tridactyla (Linnaeus)): (1) at Buldir Island in the western Aleutian Islands in 1975 (10 examined, $80 \%$ prevalence with other species of Tetrabothrius); (2) at Ugaiushak Island in 1976 (35; 46\%) and at Kodiak Island in 1977 (50; 48\%) from the northern Gulf of Alaska; (3) St. Matthew Island from the central Bering Sea in 1982 (14; 21\%); and (4) from Talan Island in the northern Sea of Okhotsk in 1988 (20\% in 30 breeding adults, $96 \%$ in 26 young of the year birds) (Hoberg, 1979, 1992; E. P. Hoberg, unpublished field data). Specimens of slaty-backed gulls, Larus schistisagus Stejneger, at the latter site were also hosts for 
multiple species of Tetrabothrius (71\% in 21 adults, $80 \%$ in 5 young of the year) (Hoberg, 1992). A diverse group of larids (overall Rissa tridactyla (206 total), R. brevirostris (Bruch) (2), Larus hyperboreus Gunnerus (13), L. schistisagus (27), L. argentatus (Pontoppidan) (12), L. heermani Cassin (6), Sterna paradisaea Pontoppidan (37) and Xema sabini (Sabine) (34), Onychoprion aleuticus (Baird) (1)) and stercorariids (S. pomarinus (14), S. parasiticus (4), and S. longicaudus (18)), representing sampling from the East Siberian Sea, the Sea of Okhotsk, Bering Sea, Gulf of Alaska and pelagic waters of the Eastern Pacific beyond the continental shelf of Washington State were not infected with T. jagerskioeldi (Supplementary Data Table 2). Thus, the occurrence of relatively great prevalence for T. jagerskioeldi in 2 populations of glaucous-winged gulls from the northern Gulf of Alaska appears notable and may reflect particular attributes of the marine ecosystem at those localities.

\section{Documenting a Tetrabothrius Fauna among Alcidae and Other Seabirds}

The actual recognized host range for $T$. jagerskioeldi cannot be confirmed unequivocally because of recognition of a putative complex of cryptic species, possibility of multispecies infections, general absence of archival specimens in museum repositories, and incomplete morphological characterization for tapeworms reported in a diverse assemblage of marine avian species. Historical records or attribution of host occurrence fall into 3 categories: (1) unsubstantiated and without documentation of provenance for geographic source; (2) records with information for host and locality but without a link to specimens and specific details of comparative morphology for parasites, and thus absence of a comparative basis to verify identification; (3) records validated by archival deposition of some or all parasite specimens and comparative morphological assessments (Table 3). In a contemporary context we would expect documentation of species richness and diversity to encompass: (1) archival deposition and biodiversity informatics within an interactive database platform and a permanent museum collection; (2) complete georeferenced field data; (3) parasite specimens prepared and evaluated based on comparative morphology and molecular characterization; (4) archival deposition of comparative morphological and molecular data; and (5) host symbiotype specimens and tissues (see Cook et al., 2016, 2017; Dunnum et al., 2017). The research community, editors, reviewers (as gatekeepers to the literature), and journals have the responsibility to build and maintain these standards (e.g., Hoberg et al., 2009).

Major monographs that explored cestode diversity in avian species and other vertebrate hosts did not include comprehensive and specific data about geographic distributions of parasites (e.g., Zschokke, 1903; Ransom, 1909; Fuhrmann, 1932; Joyeaux and Baer, 1936; Baer, 1954; Yamaguti, 1959; Schmidt, 1986; Temirova and Skrjabin, 1978; Ryzhikov et al., 1985). Following the description by Nybelin (1916), all reported T. jagerskioeldi in species lists without direct attribution to original literature (primarily in Alca torda and Cepphus grylle). Whether or not these represented independent records of occurrence cannot be determined. Additionally, voucher specimens, with few exceptions, were not archived in museum repositories from any published field collections outlined below. Further, some personal collections held by individual investigators following publication were later discarded, destroyed, or lost. Consequently, species identity for cestodes as reported in the literature (excluding the original type series for T. jagerskioeldi and T. intrepidus) can no longer be verified.

Host range reported in the most recent synoptic monograph for the Tetrabothriidae (Temirova and Skrjabin, 1978) and the most recent published review of faunal diversity (Muzaffar and Jones, 2004) cannot be accurately assessed. Temirova and Skrjabin (1978) reported T. jagerskioeldi in a stercorariid (Stercorarius parasiticus) and 6 species of alcids (Uria aalge, Cepphus grylle, C. carbo, Synthliboramphus antiquus, Fratercula arctica, and F. cirrhata) and included Chukotka, the Kurile Islands, and Barents Sea as Russian localities; published records of field collections in Chukotka have not been discovered, nor has published documentation for this cestode in tufted puffins. Muzaffar and Jones (2004) reported incomplete and incorrect data for geographic localities and also host species for T. jagerskioeldi that cannot be linked to original records (e.g., F. cirrhata, $F$. corniculata, Cepphus Columba, and B. marmoratus). Further, all putative records of $T$. jagerskioeldi from Greenland in any host species cannot be validated (Table 3).

Equivocal host and geographic records have been perpetuated downstream in the literature leading to erroneous concepts for the distribution of diversity. Similar to T. jagerskioeldi, prior records of $T$. cylindraceus and T. erostris attributed to alcids cannot be easily verified. In this context, Temirova and Skrjabin (1978) reported T. erostris in C. grylle and C. columba. According to Ransom (1909), U. aalge was a host for T. cylindraceus, a record 
which was later repeated extensively (e.g., Fuhrmann, 1932; Joyeaux and Baer, 1936; Yamaguti, 1959; Schmidt, 1986; Temirova and Skrjabin, 1978). Records secondarily attributed to Römer and Schaudinn (1918) by Muzaffar and Jones (2004) for T. erostris in C. grylle and T. cylindraceus in Uria spp. do not refer to independent field collections. Lastly, a record of $T$. macrocephalus in U. aalge attributed to von Linstow (1878) and Yamaguti (1959) cannot be validated.

Historical records, with provenance minimally based on field collections and published reports, for species of Tetrabothrius in alcid and larid seabirds are focused in the eastern North Atlantic/Russian Arctic, Greenland/ northeastern Canada, and western North Pacific/Russian Far East (Table 3). In the greater North Atlantic basin and Russian Arctic: (1) Tetrabothrius jagerskioeldi (including $T$. intrepidus) was initially recognized and described based on multiple cestode specimens in black guillemot from Sweden and the Barents Sea, Russia (Nybelin, 1916; Baylis, 1918). (2) Markov (1937, 1941) did not reveal T. jagerskioeldi or other Tetrabothrius in $52 \mathrm{U}$. lomvia and 7 C. grylle at Bezymiannaya Bay, Novaya Zemlya; T. cylindraceus occurred in $33 \%$ of 17 L. glaucous but not in Rissa tridactyla (21). (3) Belopol'skaia (1952) based on field collection in 1940-41 reported T. jagerskioeldi in black guillemot (4.5\% of 27 adults and $20 \%$ of 5 juveniles, $1-2$ intensity); Alca torda $(9.2 \%$ of 22,1$)$; Uria aalge ( $4 \%$ of 54 adults, 1); Atlantic puffin, Fratercula arctica (4.8\% of 26 adults, 1); and Stercorarius parasiticus (21\% of 30 adults, $3 ; 50 \%$ of 6 juveniles, 1 ) at the Seven Islands, Gosudarstvennogo Zapovednik in the Barents Sea. Specimens of T. jagerskioeldi were not observed or collected in black-legged kittiwakes, Rissa tridactyla (90 examined); great black-backed gull, Larus marinus Linnaeus (24); Larus argentatus (34), or Larus canus Linnaeus (31), although T. erostris and T. cylindraceus were revealed in these larids at this locality. (4) Galaktionov (1995) explored parasite diversity during 1991-93 in the Seven Islands Reserve and did not demonstrate T. jagerskioeldi or other species of Tetrabothrius among C. grylle (5 examined), U. aalge (10), U. lomvia (10), F. arctica (10), and A. torda (9). Among larids, T. erostris and T. immerinus (Abildgaard, 1790) were observed in black-legged kittiwakes, whereas herring gulls were infected with $T$. erostris; prevalence of $T$. erostris was substantially greater, and T. cylindraceus was not observed compared to data from the 1940s. (5) Galkin et al. (1994) examined 4 black guillemots and 6 thick-billed murres from Hooker Island (Franz Josef Land) and Kharlov Island (East Murman Coast) (Arctic) without observing T. jagerskioeldi;
T erostris, T. immerinus, and T. morschtini were reported in 4 species of Larus gulls and black legged kittiwakes. (6) Kuklin and Kuklina (1995) reported T. jagerskioeldi in a black guillemot but not in other alcid hosts from the region of the Kola Peninsula based on collections between 1993 and 2000.

In Greenland/northeastern Canada: (1) Ditlevsen (1914) reported T. cylindraceus in thick-billed murre and T. erostris in black guillemot from unspecified localities in Greenland; (2) Baer (1956) reported T. jagerskioeldi in black guillemot from Kangerluk (= Diskofjord), West Greenland (determined to represent an undescribed species in the present study), and razorbill from Oqaitsoq, West Greenland (redetermined as T. erostris in current study) but not thick-billed murres; other species, $T$. erostris or T. cylindraceus, were reported in larids including glaucous gull, Larus hyperboreus, Iceland gull, Larus glaucoides Meyer, Rissa tridactyla, and Arctic tern, Sterna paradise, from West Greenland. (3) Tetrabothrius jagerskioeldi was not reported from Iceland by Baer (1962), and species of Tetrabothrius were not observed in razorbills, common puffins, and a single museum specimen of the now extinct great auk (Pinguinus impennis (Linnaeus)); other tetrabothriids included T. cylindraceus in Rissa tridactyla, L. fuscus, and L. hyperboreus, and T. erostris in S. parasiticus and L. hyperboreus. (4) Threlfall (1971) found T. jagerskioeldi in common murres ( $7 \%$ of $674,1-19)$, thick-billed murres (8\% of $60,1-4)$ Atlantic puffin $(2.5 \%$ of 160,1$)$, and possibly dovekie, Alle alle (Linnaeus), (4\% of 48) across 6 geographic localities from the Northwest Atlantic, encompassing Newfoundland, Labrador, and western Greenland; also T. cylindraceus and T. erostris were found in U. aalge (near 1\%). Razorbills and black guillemots were not demonstrated as hosts for species of Tetrabothrius in these collections. (5) Muzaffar (2009) examined common (43) and thick-billed murres (57) from 5 sites spanning Coats Island, Nunavut to Labrador and West Greenland and did not reveal T. jagerskioeldi, in contrast to occurrences reported by Threlfall (1971) 40 years earlier; an unidentified species of Tetrabothrius was found in a thick-billed murre.

In the western North Pacific: (1) Krotov and Deliamure (1952) reported T. macrocephalus in marbled murrelets, Brachyramphus marmoratus, from Sakhalin Island (ca. $\left.51^{\circ} \mathrm{N}, 143^{\circ} \mathrm{E}\right)$; Tetrabothrius jagerskioeldi was not observed. (2) Belopol'skaia (1963a, 1963b) found T. jagerskioeldi in spectacled guillemots, and ancient murrelets from the Sudzukhinsky Reserve, Russian Far East. Tetrabothrius jagerskioeldi was not recognized in 7 species of Laridae, all of which had mixed-species infections of 
T. erostris and T. cylindraceus. (3) Smetanina $(1979,1981)$ reported T. jagerskioeldi as a common parasite in alcid hosts during the period of colonial nesting and postbreeding at Peter the Great Bay, adjacent to Vladivostok $\left(42^{\circ} 40^{\prime} \mathrm{N}, 132^{\circ} 00^{\prime} \mathrm{E}\right)$. Reports included cestodes in the following alcids: 5 spectacled guillemots $(11.6 \%$ of 43 examined, intensity $=1-6) ; 2$ thick-billed murres, Uria lomvia, (28\% of $7,1-11)$; and 1 ancient murrelet, Synthliboramphus antiquus $(17 \%$ of 6,6$)$. These cestodes were not reported in other alcids: rhinoceros auklet, Cerorhinca monocerata (5 examined); Uria aalge (2); and least auklet, Aethia pusilla (8). Further, species of Laridae were not reported as hosts for T. jagerskioeldi although both $T$. cylindraceus and T. erostris were commonly observed among black-tailed gull, Larus crassirostris Vieillot (115 examined); herring gull, Larus argentatus (4); common gull, Larus canus (41); and 4 species of terns. (4) Smetanina and Leonov (1984) reported T. jagerskioeldi in rhinoceros auklet from Shikhotan Island, Kurile Islands $\left(43^{\circ} 48^{\prime} \mathrm{N}, 146^{\circ} 45^{\prime} \mathrm{E}\right)$.

A conclusion that emerges is that T. jagerskioeldi is a rare tapeworm with a patchy distribution in pelagic to nearshore marine environments, showing considerable heterogeneity, with respect to prevalence and abundance, in space and time, among alcid seabirds across high-latitude seas of the Holarctic (e.g., Table 3; Supplementary Data Table 2). Prior concepts for host range in the current slice of ecological time require reevaluation. We demonstrate that the associations for T. jagerskioeldi are relatively narrow and appear to involve a more limited spectrum of alcid hosts, particularly guillemots, and less often other species of marine birds than currently assumed.

The apparent spatial patchiness for occurrence of $T$. jagerskioeldi and Tetrabothrius undescribed n. sp. among alcids contrasts with the distribution of other species of Tetrabothrius in larid hosts (Supplementary Data Table 2). Among species assemblages in sympatry involving alcids and larids, T. jagerskioeldi and Tetrabothrius undescribed n. sp. are rarely observed occurring in 1-7.5\% of hosts. In contrast, prevalence of other Tetrabothrius spp. in species of larids may approach $80-100 \%$ adjacent to some colony sites. Species diversity for Tetrabothrius in alcids and larids generally represent distinct faunas with minimal overlap that may be ecologically defined (e.g., Hoberg, 1992; Supplementary Data Table 2). These apparent differences are unlikely to be an artifact of sampling. The outlines of diversity and parasite distribution in these marine systems reflect the outcomes of ecological fitting in sloppy fitness space, interactions of opportunity for exposure and transmission determined by physical and biological oceanographic processes, and capacity of parasites to utilize host resources among alcid and larid seabirds (e.g., Hoberg and Brooks, 2008; Agosta et al., 2010; Brooks et al., 2019). Further, a sympatric assemblage of avian species is not required for transmission, as the influence of advective processes downstream and across insular systems may influence the distribution and availability of suitable and infected intermediate hosts in the water column, either limiting or expanding opportunity (e.g., Hoberg, 1995). These are dynamic systems where oscillations in temperature, water masses, production cycles, and cascades emanating from incremental climate warming and extreme events are predicted to be reflected in faunal structure for parasites (Hoberg et al., 2013, 2017).

Faunal disparity is real with respect to parasite species diversity, prevalence, and intensity and reflects the distribution and density of seabirds, macrozooplankton, other marine invertebrates, and piscine prey in nearshore and neritic habitats versus pelagic environments (Hoberg, 1996, 2005). That tetrabothriids are in circulation in common marine food webs, however, is indicated by the abundance of those species among larid hosts (high prevalence). Density and dilution in marine environments are expected to influence the distribution and availability of prey species involved in parasite transmission with respect to islands and insular systems that serve as a focus for avian activity during the breeding cycle (e.g., Hoberg, 1996). Predictable currents, advective processes, and frontal eddy systems associated with islands and archipelagos focus the distribution of pelagic prey species and secondarily directly influence patterns of foraging activity for seabirds and other vertebrate hosts (e.g., Hoberg, 1995, 1996; Hoberg and Adams, 2000).

\section{Necessity and Adequacy of Baselines for Diversity}

Baselines, against which to assess environmental stability and perturbation, are only as good as the accuracy of the species identifications, the depth of associated biodiversity informatics, the holistic approach to communitylevel collections (Schindel and Cook, 2018, Galbreath et al., 2019), and authoritative archived specimens (with integrated data) that describe an ecological assemblage in space and time (e.g., Brooks et al., 2014; Cook et al., 2016; Dunnum, 2017). Diversity (species richness, abundance, host and geographic distributions) must be explored across an entire local or regional avifauna rather 
than with a focus on specific putative host species. Evolution of diagnostic methods continues to expand, with increasingly refined molecular-based data that can contribute to accurate definitions of species limits and diversity in a phylogenetic/historical context (e.g., Brooks and McLennan, 2002; Cook et al., 2013, 2017; Colella et al., 2019; Greiman et al., 2018); integration of comparative morphology and molecular data remain a powerful foundation, although the latter could not be explored in our current study. Significantly, assumptions about host range linked to concepts of specificity are no longer supportable (e.g., Hoberg and Brooks, 2008; Nylin et al., 2018; Brooks et al., 2019). Our understanding of environmental drivers and episodic perturbation in host colonization, parasite diversification, and mosaic faunal assembly indicate that whole-ecosystem approaches are not only warranted but a necessity in identifying the outcomes of accelerating disruption of the biosphere (Brooks and Hoberg, 2000; Hoberg and Brooks, 2008; Hoberg et al., 2012; Brooks et al., 2019). Disruption modifies faunal structure through elimination of ecological constraints and by facilitating opportunities for colonization and expansion of host range that emerge from ecological fitting in sloppy fitness space (Agosta et al., 2010; Araujo et al., 2015; Hoberg and Brooks, 2015). The parameters for faunal dynamics, assembly, and diversity as identified in the Stockholm Paradigm and the DAMA protocols provide a path to anticipate and identify the outcomes of accelerating change, ecological perturbation, the nature of parasite-host systems, and potential for emerging disease in marine environments (Brooks et al., 2014; Brooks et al., 2019).

A robust understanding of parasite species diversity and distribution is critical in establishing baselines across marine ecosystems. Our current study among species of Tetrabothrius, especially in the North Pacific basin and Bering Sea ecosystem contributes to development of a specimen-centered series of baselines derived primarily from the late 1970s through the 1980s against which accelerating perturbations may be explored (e.g., broader assessments of helminth diversity in Hoberg, 1984; Hoberg et al., 2013). The 1970 s represent a tipping point and a shift to accelerated warming that has been especially manifested in Arctic and northern ecosystems (Trenberth et al., 2007; reviewed in Hoberg et al., 2017). Thus, defining the limits for T. jagerskioeldi, other species of Tetrabothrius, and a broader macroparasite fauna has implications for understanding host range, geographic/ oceanographic distributions, and the physical and biological determinants of faunal structure and assembly across evolutionary and ecological time (e.g., Galaktionov, 1995; Hoberg, 1996; Hoberg and Brooks, 2008; Cook et al., 2017; Brooks et al., 2014; Brooks et al, 2019).

Large-scale historical baselines established from specimen collections allow exploration of faunal change over time in neritic and pelagic systems (Hoberg and Adams, 2000; Hoberg, 2005), but parasites have not been regularly sampled and archived from North Pacific seabirds over the past three decades. Parasites become powerful adjuncts to studies of food habits and foraging ecology among diverse assemblages of hosts (Galaktionov, 1995; Hoberg et al., 2013). For example, Muzaffar (2009) observed a major shift in the distribution of Tetrabothrius occurring in common and thick-billed murres from West Greenland relative to intensive surveys in the late 1960s. In this regard, Threlfall (1971) had provided a baseline for comparison, reporting T. jagerskioeldi as an abundant cestode across multiple geographic sites and species of alcids; large Tetrabothrius in murres were considered to be absent 40 years later. Galaktionov (1995) also observed a substantial change in diversity and distribution for tetrabothriid faunas circulating in alcids and larids in the Seven Islands Archipelago, which was the site of inventory by Belopol'skaia (1952) in the 1940s. New patterns for host range and distribution were attributed to changing diets reflecting abundance of forage fishes: (1) absence of $T$. jagerskioeldi in alcid seabirds; (2) increasing abundance of $T$. erostris and absence of $T$. cylindraceus in Larus gulls; (3) first occurrence of T. immerinus (= T. macrocepahlus) and an undescribed species of Tetrabothrius in Rissa tridactyla (Galaktionov et. al., 1993; Galkin et al., 1994). Additionally, increasing prevalence of other cestodes, Alcataenia larina (Krabbe, 1869) in kittiwakes resulted from prey selection dominated by macrozooplankton including euphausiids and copepods. Considerable perturbation in the structure of host-parasite assemblages in Arctic and subarctic seas appear increasingly driven by climate forcing and variation in oceanographic conditions, current regimes, and range shifts. Shifting abundance of non-tetrabothriid cestodes appears related to differential prey selection (euphausiids) among kittiwakes and murres and oceanic regime shifts emerging from the Pacific Decadal Oscillation (Hoberg, 1996, 2005). Intensified current regimes and changing watermass structure through the Arctic basin were identified as drivers in an apparent range expansion from the North Pacific to the North Atlantic of a species of Alcataenia Spasskaya, 1971 in murres (Muzaffar et al., 2005; Muzaffar, 2009). Oceanic 
colonization was apparently mediated by advection and an expanding range for euphausiid crustaceans of North Pacific origin that serve as intermediate hosts. Emerging host and geographic associations for parasites have coincided with a substantial restructuring of open ocean, pelagic habitats since the 1970s.

A series of mortality events among different species of seabirds (alcids, larids, and procellariiforms) has been documented across the Northeastern Pacific (Gulf of Alaska) and into the Bering Sea over the past 2-3 decades (reviewed in Jones et al., 2019). A broad scale and ongoing shift in ecosystem structure has been linked to recurring episodes of elevated sea surface temperatures at high latitudes (Jones et al., 2019; IPCC, 2019). Signatures of oceanic warming are apparent across scales and involve: (1) outcomes of incremental climate warming over time; (2) episodic oscillations between warm and cold ocean regimes defined by such ocean-atmosphere processes as El Niño Southern Oscillation and the Pacific Decadal Oscillation (Chavez et al., 2003; Springer et al., 2007; Sydeman et al., 2015); and (3) transient and spatially persistent events of extreme atmospheric and sea surface temperatures manifested as marine heat waves (Di Lorenzo et al., 2016; reviewed in Jones et al., 2018, 2019). A decreasing extent and duration of seasonal sea ice has resulted in elevated sea surface temperatures across the Bering Sea (and Arctic Basin) and is linked to ecological cascades influencing the distribution and diversity of forage fishes and zooplankton (Post et al., 2013; Duffy-Andersen et al., 2017; Perovich et al., 2017, 2018). Shifts in ecosystem structure appear to involve the community composition of lipid-rich macrozooplankton (euphausiids-species of Thysanoessa Brandt and calanoid copepods - species of Neocalanus Sars and Calanus Leach) and forage fishes (capelin-Mallotus villosus (Müller), juvenile Alaska Pollock-Gadus chalcogrammus Pallas, and possibly Pacific sandlance-Ammodytes hexapterus Pallas) that serve as primary prey for alcids and other seabirds (e.g., Springer et al., 2007; see also Galaktionov, 1995 for discussion of helminth faunas and ecological dynamics for fishes and zooplankton in the Barents Sea).

Perturbations in ecosystem structure and dynamics are manifested in mortality events for zooplanktivorous and piscivorous seabirds through modified phenology for prey, shifts in abundance, and altered patterns of diversity that influence the availability of suitable food resources (e.g., Baduini et al., 2001; Napp and Hunt, 2001; Jones et al., 2019). The greatest sustained or persistent marine heat wave documented to date for the Gulf of Alaska and Bering Sea, during 2016-2017, resulted in extensive breeding failures and an estimated mortality event for over 1 million common murres which represent the dominant marine avian piscivores in these oceanic systems (Piatt et al., 2020). Contemporary conditions in the Bering Sea ecosystem suggest northward shifts in the distribution of primary forage fishes and macrozooplankton tracking a reduction in the range of cold water and low sea surface temperatures. Availability of historically dominant assemblages of prey species is changing in a downstream response to elevated sea surface temperatures. Disruption of trophic pathways and connectivity across the greater North Pacific is expected to result in substantial changes in the distribution and abundance of a broad array of parasites that historically have circulated respectively among assemblages of marine birds, pinnipeds and cetaceans (e.g., Hoberg et al., 2013; Brooks et al., 2019).

In an increasingly variable regime, stratification by temperature/salinity in the water column, changing water mass structure, and new current patterns, and connectivity will modify the distribution and availability of primary zooplankton and piscine prey that serve as intermediate hosts. Secondarily, a shifting spectrum for prey diversity, spatially and temporally, will influence transmission dynamics, occurrence, and abundance for a range of helminth and other parasites in marine birds (Hoberg, 1996, 2005; Mouritsen and Poulin, 2002; Muzaffar et al., 2005; Muzaffar, 2009; Hoberg et al., 2013, 2017). Anthropogenic disturbance related to fisheries and other factors will also directly influence the structure and diversity of helminth communities, especially among larids (e.g., Galaktionov, 1995; Galaktionov et al., 1993). Beyond direct mortality events related to starvation, stress, and toxic algal blooms (Jones et al., 2019), we would predict substantial changes in the distribution of characteristic assemblages of macroparasites (and other pathogens) associated with species of seabirds and a diverse assemblage of vertebrates and invertebrates (e.g., Galaktionov, 1995; Hoberg, 1996, 2005; Hoberg et al., 2013, 2017). Acquisition of a macroparasite fauna in avian hosts results from extended bouts of foraging in space and time, reflecting seasonal and finer scale interactions across neritic to pelagic environments. Detailed knowledge of specimenbased faunal diversity for parasites provides access to a cumulative snapshot of foraging behavior, prey availability, and prey selection. 
Interconnected and comparative snapshots can be assembled only through rigorous, temporally structured, resampling efforts that will provide powerful temporal and spatial perspectives and proxies for changing conditions in marine foodwebs, communities, and the continuity of trophic linkages (Hoberg et al., 2013). In the intervening decades since the core of this North Pacific inventory was assembled and archived, pervasive perturbations have been observed across the North Pacific and Bering Sea ecosystem. On expansive spatial and temporal scales the signatures for long-term incremental warming, decadal and short-term ocean-atmosphere oscillations, and emergence of extreme events are immediately apparent (Hoberg et al., 2017). Ongoing shifts in the structure of marine systems in response to temperature regimes are expected to drive changes in the diversity and distribution of assemblages of hosts and parasites with implications yet to be revealed and which are incompletely understood.

Acknowledgments - Joseph and Nella Cook, Solé, Remy, and the Cook Estancia in the shadow of Sandia Mountain contributed immeasurably to completion of our initial studies of Tetrabothrius diversity. The Museum of Southwestern Biology (MSB), Parasitology Division, University of New Mexico, and Collections Manager Sara Brant curated, archived, and databased our specimens in the Arctos platform and provided laboratory facilities, instrumentation, and general support. Specimens from field collections spanning the decades in Alaskan marine waters were provided by Robert and Virginia Rausch (including specimens from Everett L. Schiller and Francis H. "Bud" Fay) through the R. L. and V. R. Rausch Helminthological Collections at the MSB. Helminthological specimens collected during Project Chariot $(1959,1960)$ from the Cape Thompson region by L. Gerard "Jerry" Swartz were made available for evaluation. Access to the type series of $T$. jagerskioeldi was kindly facilitated by Professor Göran Andersson, Naturhistoriska Museet, Göteborg, Sweden. Access to the type series of $T$. intrepidus and other archived specimens of Tetrabothrius was made possible by Ms. Eileen Harris and Dr. Rodney Bray, the British Museum of Natural History. Successive curators, Dr. Claude Vaucher and Dr. Jean Mariaux, Museum d' Histoire Naturelle, Geneva, provided specimens collected by J. G. Baer from West Greenland. Professor Marie-Claude Durette-Desset loaned specimens of Tetrabothrius from the Museum National d'Histoire Naturelle, Paris. Original field collections spanned the North Pacific basin, extending into the Arctic: The US Geological Survey (under the former US Fish and Wildlife Service, USFWS) supported fieldwork during the Aleutian Canada Goose Recovery Program on Buldir Island and Amchitka Island $(1975,1976)$ with G. Vernon
Byrd, John Trapp, Duff H. S. Wehle, and Robert Day. USFWS supported studies of seabird parasite diversity on Ugaiushak Island (1976) and Kodiak Island (1977) during the Outer Continental Shelf Environmental Assessment Program with Duff H. S. Wehle, David Nysewander, Patricia Baird, Alan Moe, and Doug Forsell. Fieldwork with David Roseneau, Max Hoberg, and Margaret Dykes-Hoberg on St. Matthew Island (1982) was conducted in conjunction with USFWS. Pelagic collections off the continental shelf of Washington State (1982, $1985,1987)$ were organized by Sievert Rowher and staff of the Burke Memorial Washington State Museum, University of Washington, Seattle, and supported in part by Garett Eddy and assisted by Keith Aubry, Carol Spaa, and Dennis Paulson. Diversity assessments and collections were centered at Chaun Biological Station in the Russian Arctic (1981) with Svetlana Bondarenko, Vitus Kontrimavichus, Gennady Atrashkevich, Alexander Kondratiev, and Luba Kondratieva and at Talan Island (1988) with A. Kondratiev, L. Kondratieva, Alexander Kitaisky, and $\mathrm{S}$. Bondarenko under interacademy exchanges between the National Academy of Sciences (USA) and Russian Academy of Sciences with support from the Institute for Biological Problems of the North, Magadan. Diversity assessments were also facilitated by specimens provided through a considerable network of field biologists, including Richard Fitzner (Washington State, Destruction Island and Protection Island, 1981); Charles Drost (Channel Islands, 1987, 1988); Mark Phillips (Humboldt Bay, CA, 1977, 1979); Patrick Gearin (western Aleutians, 1981, 1982), Douglas Siegel-Causey (western Aleutians, 1991, 1992); Jane Homan (Point Barrow, AK, and St. Paul Island, 1979); and Jean Bédard, John Piatt, Alan Springer, and David Roseneau (St. Lawrence Island). We further acknowledge Kirill Galaktionov and Arseny Makarikov for confirmation of geographic place names and localities in the Russian Federation. And, appreciation to Kirill Galaktionov for our continuing discussions about faunal diversity in northern marine ecosystems. Lastly, Lori Hawkins provided technical assistance in preparation of our manuscript.

\section{Literature Cited}

Agosta, S.J.; Janz, N.; Brooks, D.R. 2010. How specialists can be generalists: resolving the "parasite paradox" and implications for emerging infectious disease. Zoologia 27: 151-162.

Araujo, S.B.L.; Braga, M.P.; Brooks, D.R.; Agosta, S.; Hoberg, E.P.; von Hathental, F.; Boeger, W.A. 2015. Understanding host-switching by ecological fitting. PLoS One 10 : e0139225.

Baduini, C.L.; Hyrenbach, K.D.; Coyle, K.O.; Pinchuk, A.; Mendenhall, V.; Hunt, G.L. 2001. Mass mortality of shorttailed shearwaters in the south-eastern Bering Sea during summer 1997. Fisheries Oceanography 10: 117-130. 
Baer, J.G. 1954. Revision taxonomique et étude biologique des cestodes de la famille Tetrabothriidae. Parasites d'Oiseaux de haute mer et de Mammifères marins. Mémoires de I'Université de Neuchâtel Serie in-quarto Tome 1. 121 pp.

Baer, J.G. 1956. Parasitic helminths collected in West Greenland. Meddelelser om Grønland Bd. 124. Nr. 10. pp. $5-55$.

Baer, J.G. 1962. Cestoda Vol II. The Zoology of Iceland. Copenhagen, Reykjavik. 63 pp.

Belopol'skaia, M.M. 1952. Parazitofauna morskikh vodoplavaiushchikh ptits. Lenigradskogo Universitet Uchenye Zapiski. Seria Biologicheskikh Nauk 141: 129-180.

Belopol'skaia, M.M. 1963a. Obzor parazitofauny ptits Sudzukhinskogo Zapovednika (Primor'e). Parazit Sbornik 21: 221-224.

Belopol'skaia, M.M. 1963b. Parazitofauna ptits Sudzukhinskogo Zapovednika (Primor'e) IV. Lentochnye chervii (Cestoidea). Trudy Gel'mintologicheskii Laboratoriia 13: 144-163.

Brooks, D.R.; Hoberg, E.P. 2000. Triage for the biosphere: The need and rationale for taxonomic inventories and phylogenetic studies of parasites. Comparative Parasitology 67: 1-25.

Brooks, D.R.; Hoberg, E.P.; Boeger, W.A. 2019. The Stockholm Paradigm: Climate Change and Emerging Disease. University of Chicago Press, Chicago. 423 pp.

Brooks, D.R.; Hoberg, E.P.; Gardner, S.L.; Boeger, W.; Galbreath, K.E.; Herczeg, D.; Mejía-Madrid, H.H.; Racz, E.; Tsogtsaikhan Dursahinhan, A. 2014. Finding them before they find us: informatics, parasites, and environments in accelerating climate change. Comparative Parasitology 81: 155-164.

Brooks, D.R.; McLennan, D.A. 2002. The Nature of Diversity: An Evolutionary Voyage of Discovery. University of Chicago Press, Chicago. 676 pp.

Chavez, F.P.; Ryan, J.; Lluch-Cota, S.E.; Ñiquen, C.M. 2003. From anchovies to sardines and back: multidecadal change in the Pacific Ocean. Science 299: 217-221.

Colella, J.P.; Talbot, S.L.; Brochmann, C.; Taylor, E.B.; Hoberg, E.P.; Cook, J.A. 2019. Conservation genomics in a changing Arctic. Trends in Ecology and Evolution. In press. doi: 10.1016/j.tree.2019.09.008

Cook, J.; Brochman, C.; Talbot, S.L.; Fedorov, V.; Taylor, E.; Väinölä, R.; Hoberg, E.P.; Kholodova, M.; Magnusun, M. 2013. Genetics. In: Arctic Biodiversity AssessmentStatus and Trends in Arctic Biodiversity. H. Meltofte (ed.). Conservation of Arctic Flora and Fauna, Arctic Council, Akureyi, Iceland. pp. 514-539.

Cook, J.A.; Galbreath, K.E.; Bell, K.C.; Campbell, M.L.; Carrière, S.; Colella, J.P.; Dawson, N.G.; Dunnam, J.L.; Eckerlin, R.P.; Greiman, S.E.; Federov, V.; Hass, G.M.S.; Haukisalmi, V.;
Henttonen, H.; Hope, A.G.; Jackson, D.; Jung, T.; Koehler, A.V.A.; Kinsella, M.; Krejsa, D.; Kutz, S.J.; Liphardt, S.; MacDonald, S.O.; Malaney, J.L.; Makarikov, A.; Martin, J.; Mclean, B.; Mulders, R.; Nyamsuren, B.; Talbot, S.L.; Tkach, V.; Tsvetkova, A.; Toman, H.M.; Waltari, E.; Whitman, J.; Hoberg, E.P. 2017. The Beringian Coevolution Project: holistic collections of mammals and associated parasites reveal novel perspectives on changing environments in the north. Arctic Science 3: 585-617. doi: 10.1139/ as-2016-0042

Cook, J.A.; Lacey, E.A.; Ickert-Bond, S.; Hoberg, E.P.; Galbreath, K.; Bell, K.C.; Greiman, S.; Mclean, B.S.; Edwards, S. 2016. From museum cases to the classroom: emerging opportunities for specimen-based education. In: Aspects of Biodiversity: Commemorating 225th Anniversary of the Lomonosov Zoological Museum, Moscow State University. I. Pavlinov (ed.). Archives of Zoological Museum of Lomonosov, Moscow State University 54: 787-799.

Di Lorenzo, E.; Mantua, N. 2016. Multi-year persistence of the 2014/15 North Pacific marine heatwave. Nature Climate Change 6: 1042-1047.

Ditlevsen, H. 1914. XI. Cestoder. Meddeleser om Grønland, Kjøbenhaven 23: 1119-1140.

Duffy-Anderson, J.T.; Stabeno, P.J.; Siddon, E.C.; Andrews, A.G.; Cooper, D.W.; Eisner, L.B.; Farley, E.V.; Harpold, C.E.; Heintz, R.A.; Kimmel, D.G.; Sewall, F.F.; Spear, A.H.; Yaumishii, E.C. 2017. Return of warm conditions in the southeastern Bering Sea: Phytoplankton - Fish. PloS One 12: e0178955. doi: 10.1371/journal.pone.0178955. PMID: 28658253.

Dunnum, J.L.; Yanagihara, R.; Johnson, K.M.; Armien, B.; Batsaikhan, N.; Morgan, L.; Cook, J.A. 2017. Biospecimen repositories and integrated databases as critical infrastructure for pathogen discovery and pathobiology research. PloS Neglected Tropical Disease 11: e0005133. doi: 10.1371/journal.pntd.0005133

Friesen, V.L.; Baker, A.J.; Piatt, J.F. 1996. Phylogenetic relationships with the Alcidae (Charadriiformes: Aves) inferred from total molecular evidence. Molecular Biology and Evolution 13: 359-367.

Fuhrmann, O. 1932. Les Ténias des Oiseaux. Mémoires de I'Université de Neuchâtel 8. 381 pp.

Galaktionov, K.V. 1995. Long-term changes in the helminth fauna of colonial seabirds in the Seven Islands Archipelago (Barents Sea, Eastern Murman). In: Ecology of Fjords and Coastal Waters. Skjolda. H.R.; Hopkins, C.; Erikstad, K.E.; Leinaas, H.P. (eds.). Elsevier Science, Amsterdam. pp. 489-496.

Galaktionov, K.V.; Marasaev, S.F.; Marasaeva, E.F. 1993. Parasites in maritime ecosystems. In: Environment and Ecosystems of the Franz Josef Land (Archipelago and Shelf). Matishov, G.G. (ed.). Kola Scientific Centre Press, Apatity. pp. 213-221. 
Galbreath, K.E.; Hoberg, E.P.; Cook, J.A.; Bell, K.C.; Campbell, M.L.; Dunnum, J.L.; Eckerlin, R.P.; Gardner, S.L.; Greiman, S.E.; Henttonen, H.; Agustín Jiménez, F.; Koehler, V.A.; Tkach, V.V.; Hope, A.G. 2019. Building an integrated infrastructure for exploring biodiversity: field collections and archives of mammals and parasites. Journal of Mammalogy 100: 382-393.

Galkin, A.K.; Galaktionov, K.V.; Marasaev, S.F.; Prokof'ev, V.V. 1994. Tsestody ryboiadnykh ptits O. Kharlov I Zemli Frantsa-luosifa. Parazitologiia 28: 373-383.

Greiman, S.E.; Cook, J.A.; Tkach, V.V.; Hoberg, E.P.; Menning, D.; Hope, A.G.; Sonsthagen, S.A.; Talbot, S.L. 2018.

Museum metagenomics: a novel method revealing gut helminth communities of small mammals across space and time. International Journal for Parasitology 40: 1061-1070.

Hoberg, E.P. 1979. Helminth parasites of marine birds (Charadriiformes: Alcidae and Laridae) occurring in the North Pacific Ocean and Gulf of Alaska. MSc thesis. University of Saskatchewan, Saskatoon, Canada, 1979. 121 pp.

Hoberg, E.P. 1984. Systematics, zoogeography, and ecology of platyhelminth parasites of the seabird family Alcidae (Charadriiformes: Suborder Alcae). PhD dissertation. University of Washington, Seattle. 324 pp.

Hoberg, E.P. 1987. Tetrabothrius shinni sp. n. (Eucestoda), from Phalacrocorax atriceps bransfieldensis (Pelecaniformes) in Antarctica, with comments on morphological variation and host-parasite biogeography and evolution. Canadian Journal of Zoology 65: 2969-2975.

Hoberg, E.P. 1992. Ekologiia gel'mintov morskikh ptits ostrova Talan (predvaritel'ny obzor). [Ecology of helminth parasitism among seabirds at Talan Island, USSR, a preliminary overview.] In: Prebrezhnye Ekosistemy Severnogo Okhotomor'ia Ostrov Talan. [Coastal Ecosystems in the Northern Part of the Sea of Okhotsk]. Tschernyavsky, F.B.; Kondratiev, A. la. (eds.). Institute for Biological Problems of the North, Far Eastern Branch, Russian Academy of Sciences, Magadan, Russia. pp. 116-136.

Hoberg, E.P. 1995. Historical biogeography and modes of speciation across high latitude seas of the Holarctic: concepts for host-parasite coevolution among the Phocini (Phocidae) and Tetrabothriidae (Eucestoda). Canadian Journal of Zoology 73: 45-57.

Hoberg, E.P. 1996. Faunal diversity among avian parasite assemblages: the interaction of history, ecology, and biogeography. Bulletin of the Scandinavian Society of Parasitology 6: 65-89.

Hoberg, E.P. 2005. Marine birds and their helminth parasites. In: Marine Parasitology (chap. 10, Economic, environmental, and medical importance). Rohde, K. (ed.). CSIRO, Sydney, Australia. pp. 414-421.
Hoberg, E.P.; Adams, A.M. 2000. Phylogeny, history and biodiversity: understanding faunal structure and biogeography in the marine realm. Bulletin of the Scandinavian Society of Parasitology 10: 19-37.

Hoberg, E.P.; Adams, A.M.; Rausch, R.L. 1991. Revision of the genus Anophryocephalus Baylis, 1922 from pinnipeds in the Holarctic with descriptions of Anophryocephalus nunivakensis sp. n. and $A$. eumetopii sp. n.

(Tetrabothriidae) and evaluation of host records from the Phocidae. Canadian Journal of Zoology 69: 1653-1668.

Hoberg, E.P.; Brooks, D.R. 2008. A macroevolutionary mosaic: episodic host-switching, geographic colonization, and diversification in complex host-parasite systems. Journal of Biogeography 35: 1533-1550.

Hoberg, E.P.; Brooks, D.R. 2015. Evolution in action: Climate change, biodiversity dynamics, and emerging infectious disease. Philosophical Transactions of the Royal Society B 370: 20130553. doi: 10.1098/rstb.2013.0553

Hoberg, E.P.; Cook, J.A.; Agosta, S.J.; Boeger, W.; Galbreath, K.E.; Laaksonen, S.; Kutz, S.J.; Brooks, D.R. 2017. Arctic systems in the Quaternary: ecological collision, faunal mosaics, and the consequences of wobbling climate. Journal of Helminthology 91: 409-421. doi: 10.1017/ S0022149X17000347

Hoberg, E.P.; Galbreath, K.E.; Cook, J.A.; Kutz, S.J.; Polley, L. 2012. Northern host-parasite assemblages: history and biogeography on the borderlands of episodic climate and environmental transition. In: Advances in Parasitology, vol. 79. Rollinson, D.; Hays, S.I. (eds.). Elsevier, Amsterdam. pp. 1-97.

Hoberg, E.P.; Kutz, S.J.; Cook, J.A.; Galaktionov, K.; Haukisalmi, V.; Henttonen, H.; Laaksonen, S.; Makarikov, A.; Marcogliese, D.J. 2013. Parasites in terrestrial, freshwater and marine systems. In: Arctic Biodiversity AssessmentStatus and Trends in Arctic Biodiversity. Meltofte, H. (ed.). Conservation of Arctic Flora and Fauna, Arctic Council, Akureyi, Iceland. pp. 476-505.

Hoberg, E.P.; Pilitt, P.A.; Galbreath, K.E. 2009. Why museums matter: A tale of pinworms (Oxyuroidea: Heteroxynematidae) among pikas (Ochotona princeps and O. collaris) in the American west. Journal of Parasitology 95: 490-501.

Hurrell, J.W.; Kushnir, Y.; Otterson, G.; Visbeck, M. 2003. An overview of the North Atlantic Oscillation. Geophysical Monographs 134: 1-35.

[ICZN] International Commission for Zoological Nomenclature. 1999. International Code for Zoological Nomenclature. 4th ed. International Trust for Zoological Nomenclature, London.

IPCC, 2019: Summary for Policymakers. In: IPCC Special Report on the Ocean and Cryosphere in a Changing Climate. Pörtner, H.-O.; Roberts, D.C.; Masson-Delmotte, V.; Zhai, P.; Tignor, M.; Poloczanska, E.; Mintenbeck, K.; 
Nicolai, M.; Okem, A.; Petzold, J.; Rama, B.; Weyer, N. (eds.). In press.

Jones, T.; Divine, L.M.; Renner, H.; Knowles, S.; Lefebvre, K.A.; Burgess, H.K.; Wright, C.; Parrish, J.K. 2019. Unusual mortality of tufted puffins (Fratercula cirrhata) in the eastern Bering Sea. PLoS ONE 14: e0216532. doi: 10.1371/ journal.pone.0216532

Jones, T.; Parrish, J.K.; Peterson, W.T.; Bjorkstedt, E.P.; Bond, N.A.; Ballance, L.T.; Bowes, V.; Hipfner, J.M.; Burgess, H.K.; Dolliver, J.E.; Lindquist, K.; Lindsey, J.; Nevins, H.M.; Robertson, R.R.; Roletto, J.; Wilson, L.; Joyce, T.; Harvey, J. 2018. Massive mortality of a planktivorous seabird in response to a marine heatwave. Geophysical Research Letters 45: 3193-3202. doi: 10.1002/2017GL076164

Joyeux, C.; Baer, J.G. 1936. Faune de France 30. Cestodes. Librairie de la Faculte des Sciences, Paris. 613 pp.

Krotov, A.I.; Deliamure, S.A. 1952. K faune paraziticheskikh chervei mlekopitaiushchikh i ptits SSSR. Trudy Gel'mintologichesky Laboratoriia 6: 278-292.

Kuklin, V.V.; Kuklina, M.M. 2005. Helminths of Birds of the Barents Sea: Fauna, Ecology and Influence on the Hosts. Kola Scientific Centre of the Russian Academy of Sciences Press, Apatity. [In Russian]

Mariaux, J.; Kuchta, R.; Hoberg, E.P. 2017. Tetrabothriidea Baer, 1954. In: Planetary Biodiversity Inventory (20082017): Tapeworms from Vertebrate Bowels of the Earth. Caira, J.N.; Jensen, K. (eds.). University of Kansas, Natural History Museum, Special Publication No. 25. Lawrence, Kansas. pp. 357-370.

Markov, G.S. 1937. Vozrastnye izmeneniia parazitofauny Novo-Zemel'skoii kaiiry (Uria lomvia lomvia) Trudy Leningradskogo Obshchestva Estestvoispytateleii 66: 456-466.

Markov, G.S. 1941. Parasitic worms of birds of Bezymiannaya Bay (Novaya Zemlya). Reports USSR Academy of Sciences 30: 579-582.

Moum, T.; Johansen, S.; Erikstad, K.E.; Piatt, J.F. 1994. Phylogeny and evolution of the auks (subfamily Alcinae) based on mitochondrial DNA sequences. Proceedings of the National Academy of Sciences (USA) 91: 7912-7916.

Mouritsen, K.M.; Poulin, R. 2002. Parasitism, climate oscillations, and the structure of natural communities. Oikos 97: 462-468.

Murav'eva, S.I.; Popov, V.N. 1976. Sistematicheskoe polozhenie i neketorye dannye ob ekologii Anophryocephalus skrjabini (Cestoda: Tetrabothriidae) parazita lastonogikh. Zoologicheskie Zhurnal 55: 1247-1250.

Muzaffar, S.B. 2009. Helminths of murres (Alcidae: Uria spp.): markers of ecological change in the marine environment. Journal of Wildlife Diseases 45: 672-683. doi: 10.7589/0090-3558-45.3.672
Muzaffar, S.B.; Hoberg, E.P.; Jones, I.A. 2005. Possible recent range expansion for Alcataenia longicervica (Eucestoda: Dilepididae) parasitic in murres (Uria spp.) into the North Atlantic. Marine Ornithology 33: 189-191.

Muzaffar, S.B.; Jones, I.A. 2004. Parasites and diseases of the auks (Alcidae) of the world and their ecology - A review. Marine Ornithology 32: 121-146.

Napp, J.M.; Hunt, G.L., Jr. 2001. Anomalous conditions in the south-eastern Bering Sea 1997: linkages among climate, weather, ocean, and biology. Fisheries and Oceanography 10: 61-68.

Nybelin, O. 1916. Neue Tetrabothriiden aus Vogel. Zoologischen Anzeiger 47: 297-301.

Nylin, S.; Agosta, S.; Bensch, S.; Boeger, W.A.; Braga, M.P.; Brooks, D.R.; Forister, M.L.; Hambäck, P.A.; Hoberg, E.P.; Nyman, T.; Schäpers, A.; Stigall, A.L.; Wheat, C.W.; Österling, M.; Janz, N. 2018. Embracing colonizations: a new paradigm for species association dynamics. Trends in Ecology \& Evolution 33: 4-14. doi: 10.1016/j. tree.2017.10.005

Perovich, D.; Meier, W.; Tschdi, M.; Farrell, S.; Gerland, S.; Hendricks, S.; Krumpen, T.; Hass, C. 2017. Sea ice cover. [In State of the Climate, 2016.] Bulletin of the American Meteorological Society 98: S131-S133.

Perovich, D.; Meier, W.; Tschudi, M.; Farrell, S.; Hendricks, S.; Gerland, S.; Haas, C.; Krumpen, T.; Polashenski, C.; Ricker, R.; Webster, M. 2018. Sea ice. In: Arctic Report Card 2018. https://www.arctic.noaa.gov/Report-Card/ Report-Card-Archive

Piatt JF, Parrish JK, Renner HM, Schoen SK, Jones TT, Arimitsu ML, et al. (2020) Extreme mortality and reproductive failure of common murres resulting from the northeast Pacific marine heatwave of 2014-2016. PLoS ONE 15(1): e0226087. https://doi.org/10.1371/journal. pone. 0226087

Post, E.; Bhatt, U.S.; Bitz, C.M.; Brodie, J.F.; Fulton, T.L.; Hebblewhite, M.; Kerby, J.; Kutz, S.J.; Stirling; I.; Walker, D.A. 2013. Ecological consequences of sea-ice decline. Science 341: 519-524.

Ransom, H.B. 1909. The Taenioid cestodes of North American birds. US National Museum Bulletin 69: 1-141.

Römer, F.; Schaudinn, F. 1918. Fauna Arctica. Gustav Fischer, Jena, Germany.

Ryzhikov, K.M.; Rysavý, B.; Khokhlova, I.G.; Tolkatcheva, L.M.; Kornyushin, V.V. 1985. Helminths of Fish-Eating Birds of the Palearctic Region II. Cestoda and Acanthocephales. USSR Academy of Sciences, Helminthological Laboratory, Moscow.

Schindel, D.E.; Cook, J.A. 2018. The next generation of natural history collections. PLoS Biology 16: e2006125.

Schmidt, G.D. 1986. Handbook of Cestode Identification. CRC Press, Boca Raton, LA. 
Smetanina, Z.B. 1979. Tsestody ryboiadnykh ptits primorskogo kraia. Materialy nauchnoii konferentsii vsesoyznogo obshchestva gel'mintologov Vypusk 31. Tsestody i Tsestodzy. Akademii Nauk SSSR. Laboratoria Gelmintologii, Moskva: Akademii Nauk USSR. pp. 120-128.

Smetanina, Z.B. 1981. Gel'minty morskikh ryboiadnykh ptits Zaleva Petra Velikogo. Biologiia I Sistematika Gel'mintov Zhivotnykh Dal'nevo Vostoka. Akad Nauk SSSR., Dal'nevostochnyi Nauchnyi Tsentr, Vladivostok. pp. 71-81.

Smetanina, Z.B.; Leonov, V.A. 1984. Gel'minty riboiadnykh ptits Kuril'skikh Ostrov. Biologiia I Taksonomiia Gel'mintov Zhivotnikh I Cheloveka. 34: 59-66.

Smith, N.A. 2011. Taxonomic revision and phylogenetic analysis of the flightless Mancallinae (Aves, Pan-Alcidae). ZooKeys 91: 1-116. doi: 10.3897/zookeys.91.709

Springer, A.M.; Byrd, G.V.; Iversen, S.J. 2007. Hot oceanography: planktivorous seabirds reveal ecosystem responses to warming of the Bering Sea. Marine Ecology Progress Series 352: 289-297. doi: 10.3354/meps07080

Sydeman, W.J.; Poloczanska, E.; Reed, T.E.; Thompson, S.A. 2015. Climate change and marine vertebrates. Science 350: $772-777$.
Temirova, S. I.; Skrjabin, A. S. 1978. Tetrabotriaty i mezotsestoidaty lentochnye gel'minty ptits i mlekopitaiushchikh. Osnovy Tsestodologii 9. Akademii Nauk SSR, Moscow.

Threlfall, W. 1971. Helminth parasites of alcids in the northwestern North Atlantic. Canadian Journal of Zoology 49: 461-466.

Trenberth, K.E.; Jones, P.D.; Ambenje, P.; Bojariu, R.; Easterling, D.; Klein Tank, A.; Parker, D.; Rahimzadeh, F.; Renwick, J.A.; Rusticucci, M.; Soden, B.; Zhai, P. 2007. Observations: surface and atmospheric climate change. In: Climate Change 2007: The Physical Science Basis. Contribution of Working Group I to the Fourth Assessment Report of the Intergovernmental Panel on Climate Change. Solomon, S.; Qin, D.; Manning, M.; Chen, Z.; Marquis, M.; Averyt, K.B.; Tignor, M.; Miller, H.L. (eds.). Cambridge University Press, Cambridge, UK. pp. 236-335.

von Linstow, O. 1878. Compendium der Helminthologie. Hahnsche Buchhandlung, Hannover, Germany.

Yamaguti, S. 1959. Systema Helminthum. Vol II. The Cestodes of Vertebrates. Interscience Publishers, New York.

Zschokke. 1903. Die Arktischen Cestoden. In: Fauna Arctica. Römer, F.; Schaudinn, F. (eds.). Gustav Fischer, Jena, Germany.

Supplementary data tables follow.

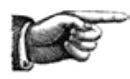


Supplementary Data Table 1. Field Data with Geo-Referencing, Dates, and Collectors for Specimens of Alcidae, Some Laridae, and Other Seabirds Examined for Helminth Parasites from the Greater North Pacific Basin (1949-1992)

\section{Aleutian Islands, Alaska}

- Amchitka Island, Constantine Harbor, Rat Islands, Bering Sea (ca. $\left.59^{\circ} 30^{\prime} \mathrm{N}, 179^{\circ} 00^{\prime} \mathrm{E}\right)$

March 1952 / R. L. Rausch

May 1976 / E. P. Hoberg

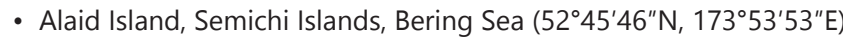
August 1992 / D. Siegel-Causey

- Attu Island (Holtz Bay), Near Islands, Bering Sea (52 $56^{\prime} 50^{\prime \prime} N$, $\left.173^{\circ} 11^{\prime} 31^{\prime \prime} \mathrm{E}\right)$

July 1991, August 1992 / D. Siegel-Causey

- Attu Island (Etienne Bay), Near Islands, Bering Sea $\left(52^{\circ} 53^{\prime} 53^{\prime \prime} \mathrm{N}\right.$, $\left.172^{\circ} 34^{\prime} 56^{\prime \prime} \mathrm{E}\right)$

August 1992 / D. Siegel-Causey

- Buldir Island, Bering Sea (ca. 52² $\left.21^{\prime} \mathrm{N}, 175^{\circ} 56^{\prime} \mathrm{E}\right)$

July 1974 / C. P. Dau, G. V. Byrd, M. H. Dick

August 1975 / E. P. Hoberg

July 1982 / D. Forsell

August 1987 / D. Nysewander

August 1991 / D. Siegel-Causey

- Kiska Island, Kiska Harbor, Bering Sea $\left(51^{\circ} 58^{\prime} 01^{\prime \prime} \mathrm{N}, 177^{\circ} 33^{\prime} 50^{\prime \prime} \mathrm{E}\right)$

August 1992 / D. Siegel-Causey

- Niztki Island (Bozo Cove), Semichi Islands (5244'28"N, $\left.173^{\circ} 59^{\prime} 08^{\prime \prime} \mathrm{E}\right)$

August 1991 / D. Siegel-Causey

- South of Western Aleutian Islands, Pelagic Habitat, North Pacific (ca. $50-51^{\circ} \mathrm{N}, 172-174^{\circ} \mathrm{E}$ )

June-July 1981 / P. J. Gearin

14 July 1981 / P. J. Gearin $\left(50^{\circ} 03^{\prime} N^{\prime} 173^{\circ} 08.6^{\prime} \mathrm{E}\right)$

June 1982/ P. J. Gearin

\section{Arctic Basin and Chukchi Sea}

- Little Diomede Island, Bering Strait $\left(65^{\circ} 45^{\prime} 42^{\prime \prime} \mathrm{N}, 168^{\circ} 57^{\prime} 06^{\prime \prime} \mathrm{W}\right)$ 15 August 1984 / L. Lowry

- Point Barrow, Alaska, Chukchi Sea $\left(71^{\circ} 16^{\prime} \mathrm{N}, 156^{\circ} 50^{\prime} \mathrm{N}\right)$

May 1958 / R. L. Rausch

August 1979 / J. Homan

- Cape Thompson, Alaska, Chukchi Sea (ca. $68^{\circ} 06^{\prime} \mathrm{N}, 165^{\circ} 46^{\prime} \mathrm{W}$ )

June 1959 / L. G. Swartz

June 1960 / L. G. Swartz

July 1976 / D. G. Roseneau, A. M. Springer

July 1977 / D. G. Roseneau, A. M. Springer
- Cape Lisburne, Alaska, Chukchi Sea (ca. $68^{\circ} 52^{\prime} \mathrm{N}, 166^{\circ} 12^{\prime} \mathrm{W}$ )

July 1977 / D. G. Roseneau, A. M. Springer

- Chaun Bay (Chaun Biological Station), East Siberian Sea, Russia (ca. $\left.68^{\circ} 44^{\prime} \mathrm{N}, 170^{\circ} 36^{\prime} \mathrm{E}\right)$

July-August 1981 / V. Kontrimavichus, S. Bondarenko, A. la. Kondratiev, L. Kondratieva, G. Atrashkevich, E. P. Hoberg

\section{Bering Sea}

- St. Paul Island (Pribilof Islands), Bering Sea $\left(57^{\circ} 10^{\prime} \mathrm{N}, 170^{\circ} 20^{\prime} \mathrm{W}\right)$ July 1979 / J. Homan

June 1987 / G. V. Byrd

- St. George Island (Pribilof Islands), Bering Sea (56 $36^{\prime} 00^{\prime \prime} \mathrm{N}$, $\left.169^{\circ} 32^{\prime} 00^{\prime \prime} \mathrm{W}\right)$

June 1987 / G. V. Byrd

- Pribilof Islands, Pelagic (no specific geo coordinates)

August 1974 / US Fish and Wildlife Service

- Nunivak Island, Nash Harbor, Bering Sea $\left(66^{\circ} 00^{\prime} \mathrm{N}, 166^{\circ} 00^{\prime} \mathrm{W}\right)$

August 1949 / P. J. Brandly

- St. Matthew Island, Bering Sea (ca. $60^{\circ} 20^{\prime} \mathrm{N}, 171^{\circ} 00^{\prime} \mathrm{W}$ ) July-August 1982 / E. P. Hoberg, M. Dykes-Hoberg, M. K. Hoberg, D. G. Roseneau

July 1983 / A. M. Springer

- St. Lawrence Island, Bering Sea (ca. $63^{\circ} 45^{\prime} \mathrm{N}, 171^{\circ} 40^{\prime} \mathrm{W}$ ) May 1950 / E. L. Schiller

18 August 1950 / E. L. Schiller / (6340'04"N, 170 34'08"W)

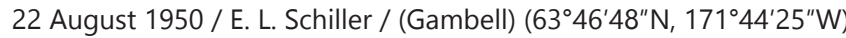
5 August 1956 / F. H. Fay / Boxer Bay $\left(63^{\circ} 20^{\prime} 21^{\prime \prime} N\right.$, 171 $\left.34^{\prime} 25^{\prime \prime} W\right)$ July 1959 / R. L. Rausch

August 1964 / J. Bédard / (Gambell) (6346'48"N, 17144'25"W)

10 and 27 July 1966 / J. Bédard / (Gambell) (6346'48"N $\left.171^{\circ} 44^{\prime} 25^{\prime \prime} \mathrm{W}\right)$

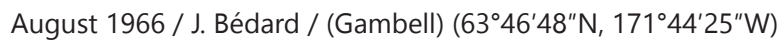

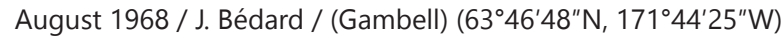

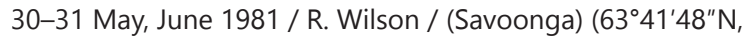
$\left.170^{\circ} 27^{\prime} 39^{\prime \prime} \mathrm{W}\right)$

19 July 1981 / D. G. Roseneau, A. Springer / (Savoonga) (6341'48"N, $\left.170^{\circ} 27^{\prime} 39^{\prime \prime} \mathrm{W}\right)$

June 1982 / R. L. Rausch / (Savoonga) (6341'48"N, 170²7'39"W)

June 1983 / R. L. Rausch

18 June 1987 / J. Piatt

- Sledge Island, Bering Sea $\left(64^{\circ} 29^{\prime} 45^{\prime \prime} \mathrm{N}, 166^{\circ} 12^{\prime} 08^{\prime \prime} \mathrm{W}\right)$

July 1969 / R. L. Rausch

- Wales, Alaska, Bering Sea $\left(65^{\circ} 36^{\prime} \mathrm{N}, 168^{\circ} 05^{\prime} \mathrm{W}\right)$

22 March 1966 / R. L. Rausch

- Bering Sea, North Central (no specific coordinates)

1976, 1977 / US Fish and Wildlife Service 


\section{Gulf of Alaska}

- Ugaiushak Island, Gulf of Alaska $\left(56^{\circ} 47^{\prime} \mathrm{N}, 156^{\circ} 41^{\prime} \mathrm{W}\right)$

May-July 1976 / E. P. Hoberg, D. H. S. Wehle

- Central Island, Gulf of Alaska ( $\left.56^{\circ} 51^{\prime} \mathrm{N}, 156^{\circ} 53^{\prime} \mathrm{W}\right)$

June 1976 / E. P. Hoberg, D. H. S. Wehle

- Chowiet Island, Semidi Islands, Gulf of Alaska (ca. $56^{\circ} 02^{\prime} \mathrm{N}$, $\left.156^{\circ} 45^{\prime} \mathrm{W}\right)$

June 1976 / G. C. Burrell

- Big Koniuji Island, Shumagin Islands, Gulf of Alaska (ca. $55^{\circ} 03^{\prime} \mathrm{N}$, $159^{\circ} 35^{\prime} \mathrm{W}$ )

July 1976 / US Fish and Wildlife Service

- Kodiak Island, Uganik Bay, Gulf of Alaska $\left(57^{\circ} 47^{\prime} 21^{\prime \prime} \mathrm{N}\right.$, $153^{\circ} 31^{\prime} 47^{\prime \prime}$ W)

June 1953 / R. L. Rausch

- Kodiak Island, Uyak Bay, Browns Lagoon, Gulf of Alaska $\left(57^{\circ} 42^{\prime} 52^{\prime \prime} \mathrm{N}, 153^{\circ} 56^{\prime} 51^{\prime \prime} \mathrm{W}\right)$

June 1953 / R. L. Rausch

- Kodiak Island, Chiniak Bay, Gulf of Alaska $\left(57^{\circ} 49^{\prime} \mathrm{N}, 152^{\circ} 30^{\prime} \mathrm{W}\right)$

June-July 1977 / E. P. Hoberg, D. Nysewander

- Puffin Island, Kodiak Island, Chiniak Bay, Gulf of Alaska $\left(57^{\circ} 46^{\prime} \mathrm{N}\right.$, $\left.152^{\circ} 26^{\prime} \mathrm{W}\right)$

10 July 1977 / E. P. Hoberg

24 July 1977 / E. P. Hoberg

- Sitkalidik Island, Kodiak Island region, Gulf of Alaska $\left(57^{\circ} 07^{\prime} \mathrm{N}\right.$, $\left.153^{\circ} 10^{\prime} \mathrm{W}\right)$

8 July 1977 / P. Baird, A. Moe

- Middleton Island, Gulf of Alaska $\left(59^{\circ} 29^{\prime} \mathrm{N}, 146^{\circ} 28^{\prime} \mathrm{W}\right)$

June 1956 / R. L. Rausch

November 1956 / R. L. Rausch

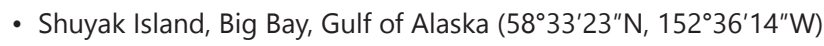
November 1954 / R. L. Rausch

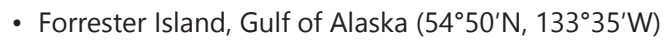

July 1976 / A. DeGange

- Gulf of Alaska, North Central (no specific geo coordinates) 1969, 1970, 1971 / US Fish and Wildlife Service

\section{Eastern North Pacific/Washington State to California}

\section{Washington State, USA}

- Grays Marine Canyon (Washington pelagic zone) $\left(46^{\circ} 55^{\prime} \mathrm{N}\right.$, $\left.124^{\circ} 46^{\prime} \mathrm{W}\right)$

8 September 1982 / E. P. Hoberg, D. R. Paulson, K. B. Aubry

31 August 1985 / E. P. Hoberg, S. Rowher, K. B. Aubry, C. Spaa

21 September 1985 / E. P. Hoberg, G. Eddy, S. Rowher

21 August 1987 / E. P. Hoberg, S. Rowher, K. B. Aubry
- Protection Island, Strait of Juan de Fuca $\left(48^{\circ} 08^{\prime} \mathrm{N}, 122^{\circ} 55^{\prime} \mathrm{W}\right)$ July 1981 / R. Fitzner

- Destruction Island, Washington, Eastern North Pacific $\left(47^{\circ} 41^{\prime} \mathrm{N}\right.$, $122^{\circ} 55^{\prime} \mathrm{W}$ )

July 1981 / R. Fitzner

- San Juan Island, Friday Harbor, Washington $\left(48^{\circ} 32^{\prime} 7^{\prime \prime} \mathrm{N}\right.$, $123^{\circ} 1^{\prime} 52^{\prime \prime} \mathrm{W}$ )

January 1981 / E. P. Hoberg

- San Juan Island, Wescott Bay, Washington (ca. $48^{\circ} 30^{\prime} \mathrm{N}, 123^{\circ} 05^{\prime} \mathrm{W}$ ) February 1982 / W. G. English

- Pt. Roberts (Southern Strait of Georgia $\left[49^{\circ} 00^{\prime} \mathrm{N}, 123^{\circ} 05^{\prime} \mathrm{W}\right]$ ) January 1964 / R. A. Ryder

- Sequim Bay, Olympic Peninsula, Strait of Juan de Fuca (ca. $48^{\circ} 05^{\prime} \mathrm{N}, 123^{\circ} 00^{\prime} \mathrm{W}$ )

November 1981 / E. P. Hoberg, R. Fitzner

\section{California, USA}

- Humboldt Bay, Eastern North Pacific (ca. $40^{\circ} 49^{\prime} \mathrm{N}, 124^{\circ} 10^{\prime} \mathrm{W}$ ) June 1977 and 1979 / M. Phillips

- Santa Barbara Island (Channel Islands), Eastern North Pacific (ca. $\left.33^{\circ} 28^{\prime} 30^{\prime \prime} \mathrm{N}, 119^{\circ} 02^{\prime} 13^{\prime \prime} \mathrm{W}\right)$

10 June 1987 / C. Drost

12 May 1988 / C. Drost

\section{Sea of Okhotsk, Russia}

- Magadan, coastal zone (ca. 59 $\left.35^{\prime} \mathrm{N}, 150^{\circ} 45^{\prime} \mathrm{E}\right)$

August 1981 / A. la. Kondratiev

- Khmotiyevskogo Peninsula (near Talan Island), northern Sea of Okhotsk (ca. $59^{\circ} 18^{\prime} \mathrm{N}, 148^{\circ} 56^{\prime} \mathrm{E}$ )

30 July 1988 / L. Kondratieva

- Talan Island Northern Sea of Okhotsk (ca. 59 $19^{\prime} \mathrm{N}, 149^{\circ} 06^{\prime} \mathrm{E}$ )

July 1988 / E. P. Hoberg, A. la. Kondratiev, L. Kondratieva, S. Bondarenko

September 1988 


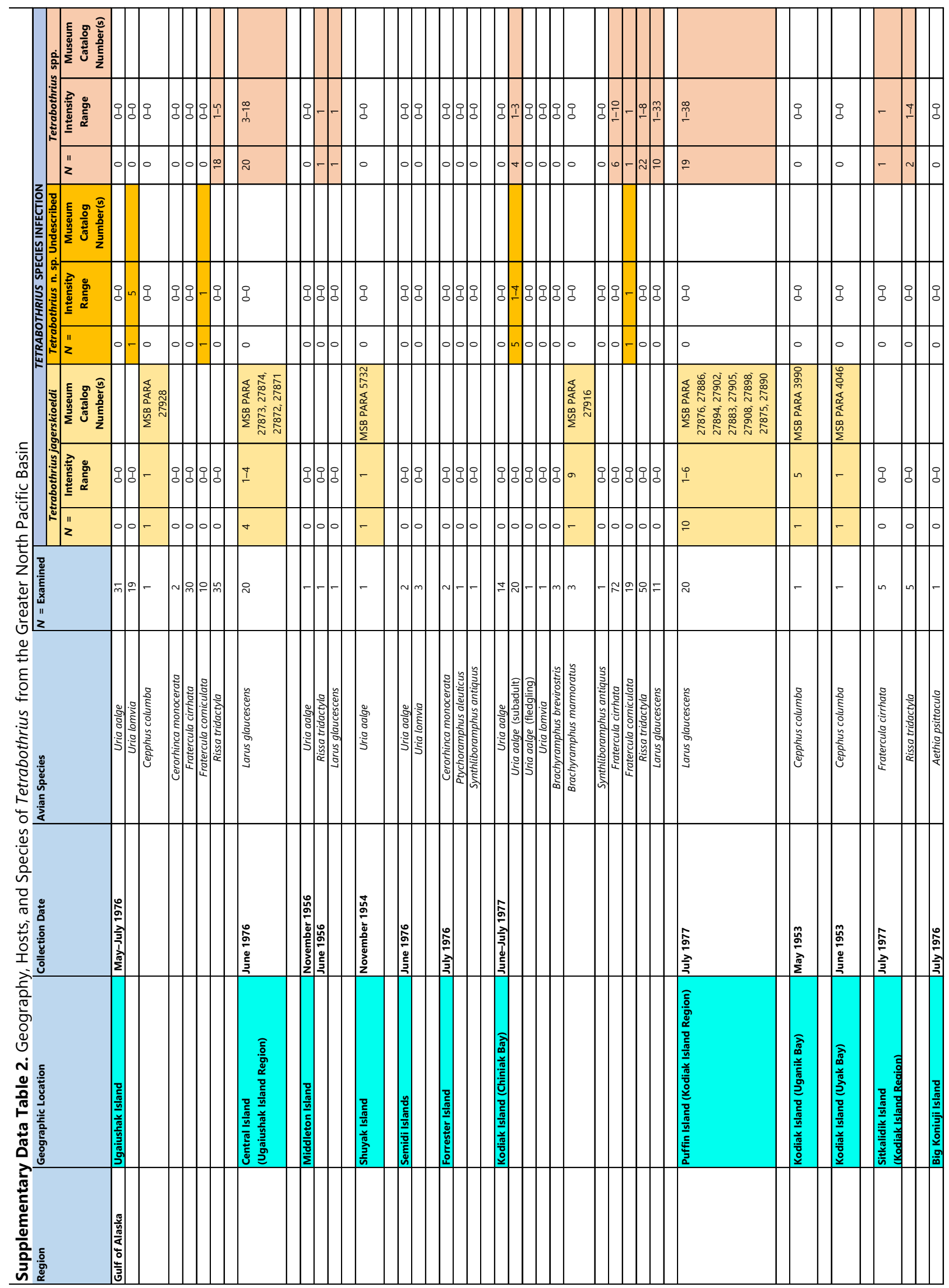




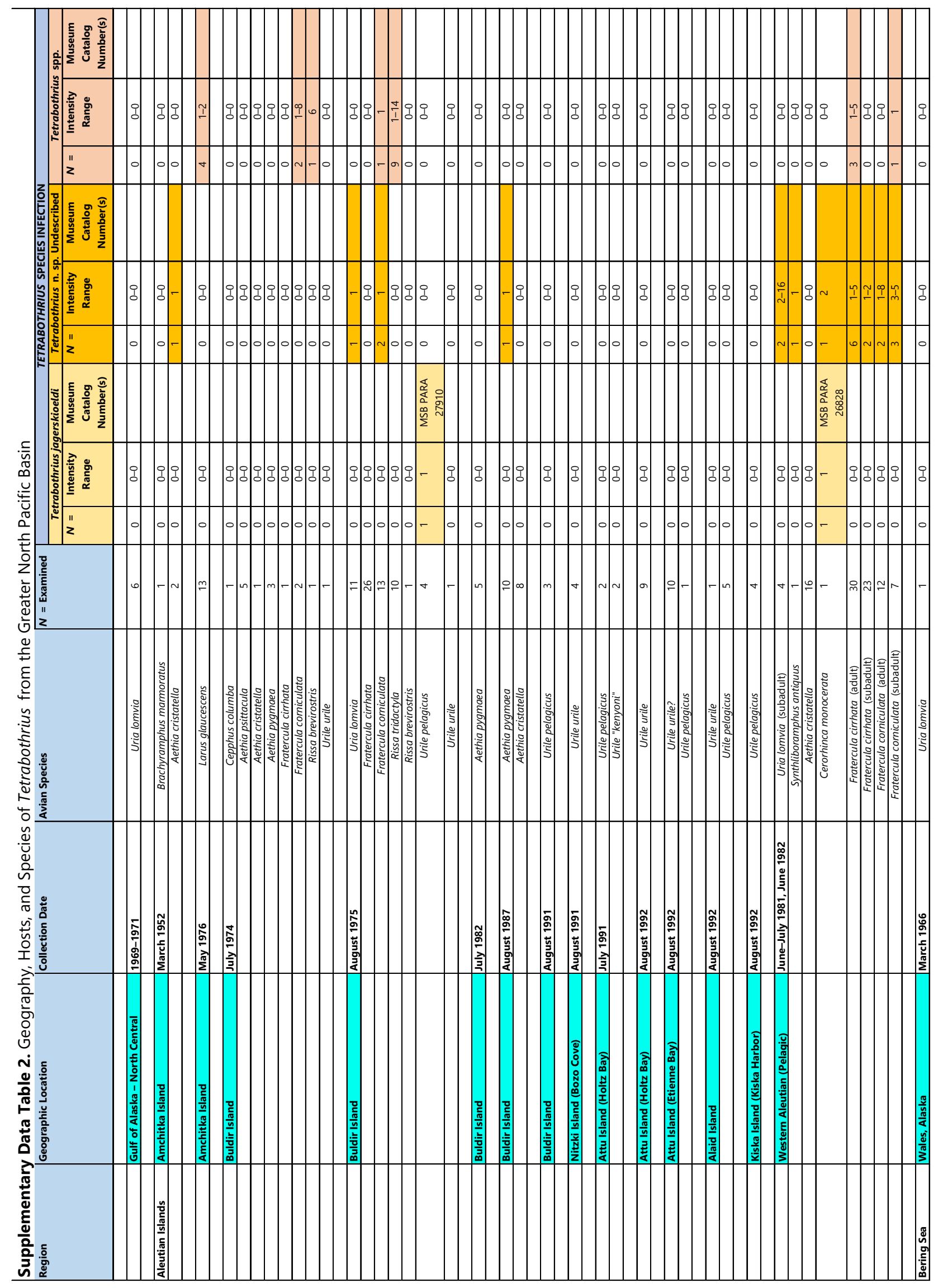




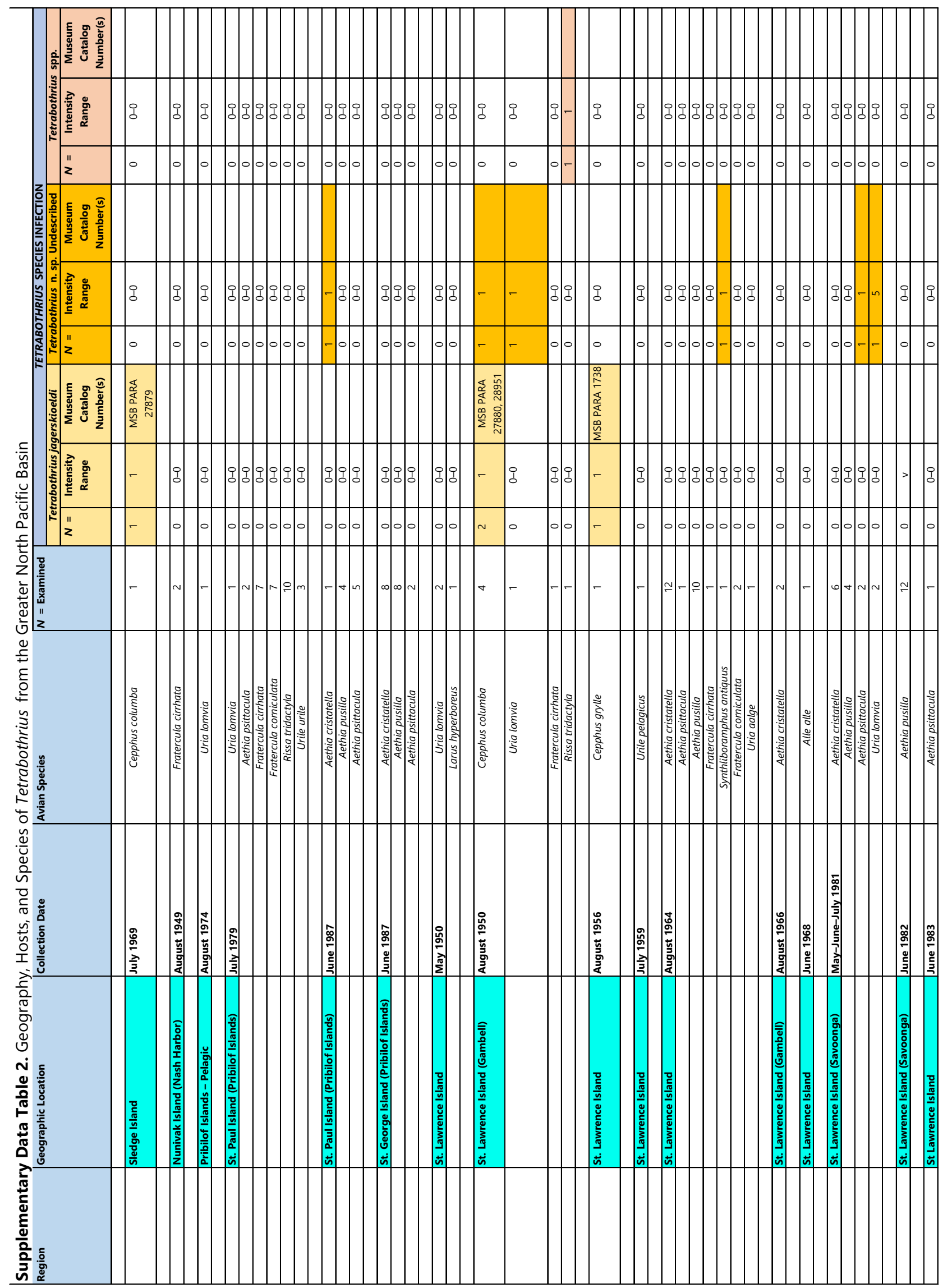




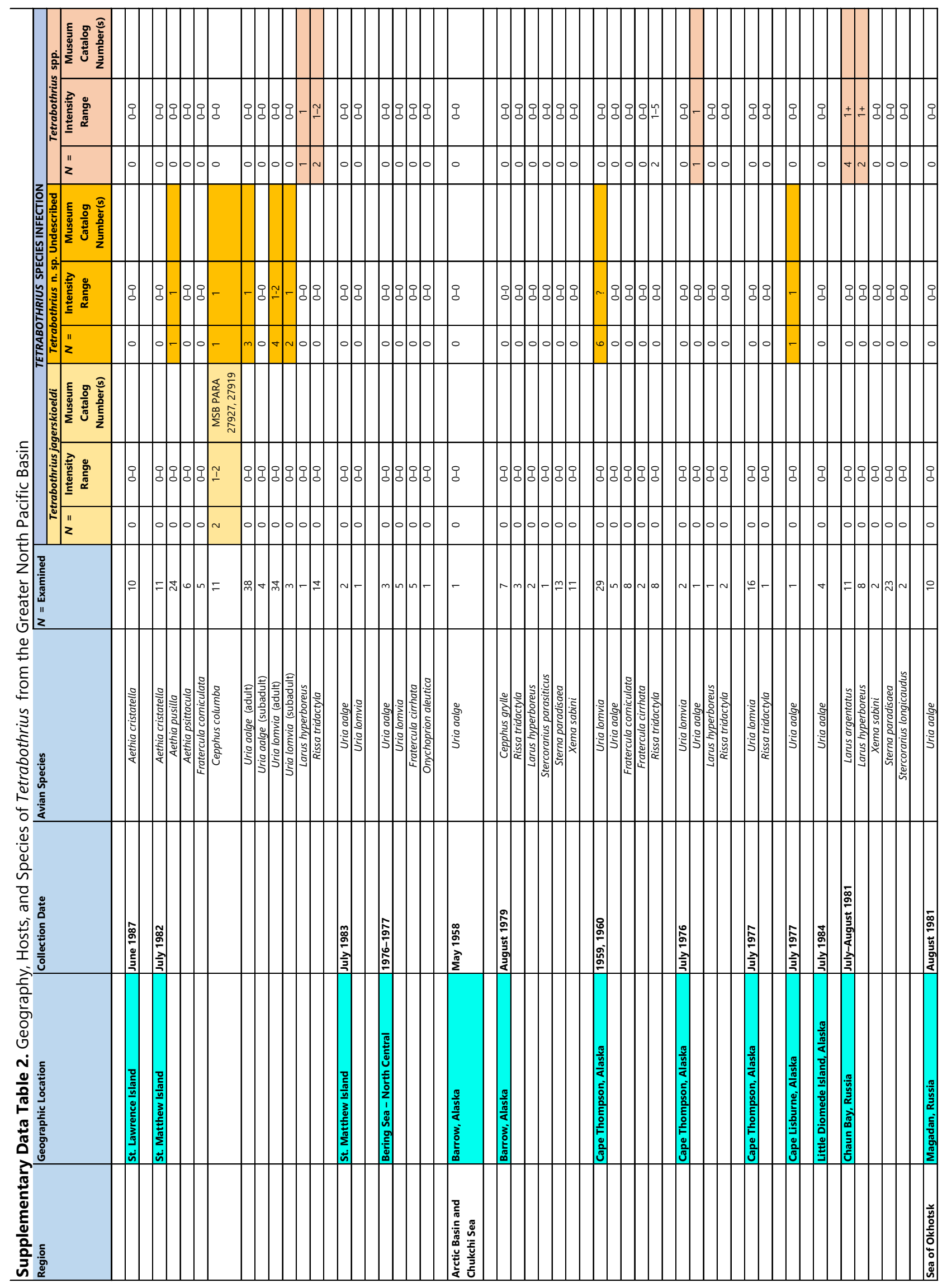




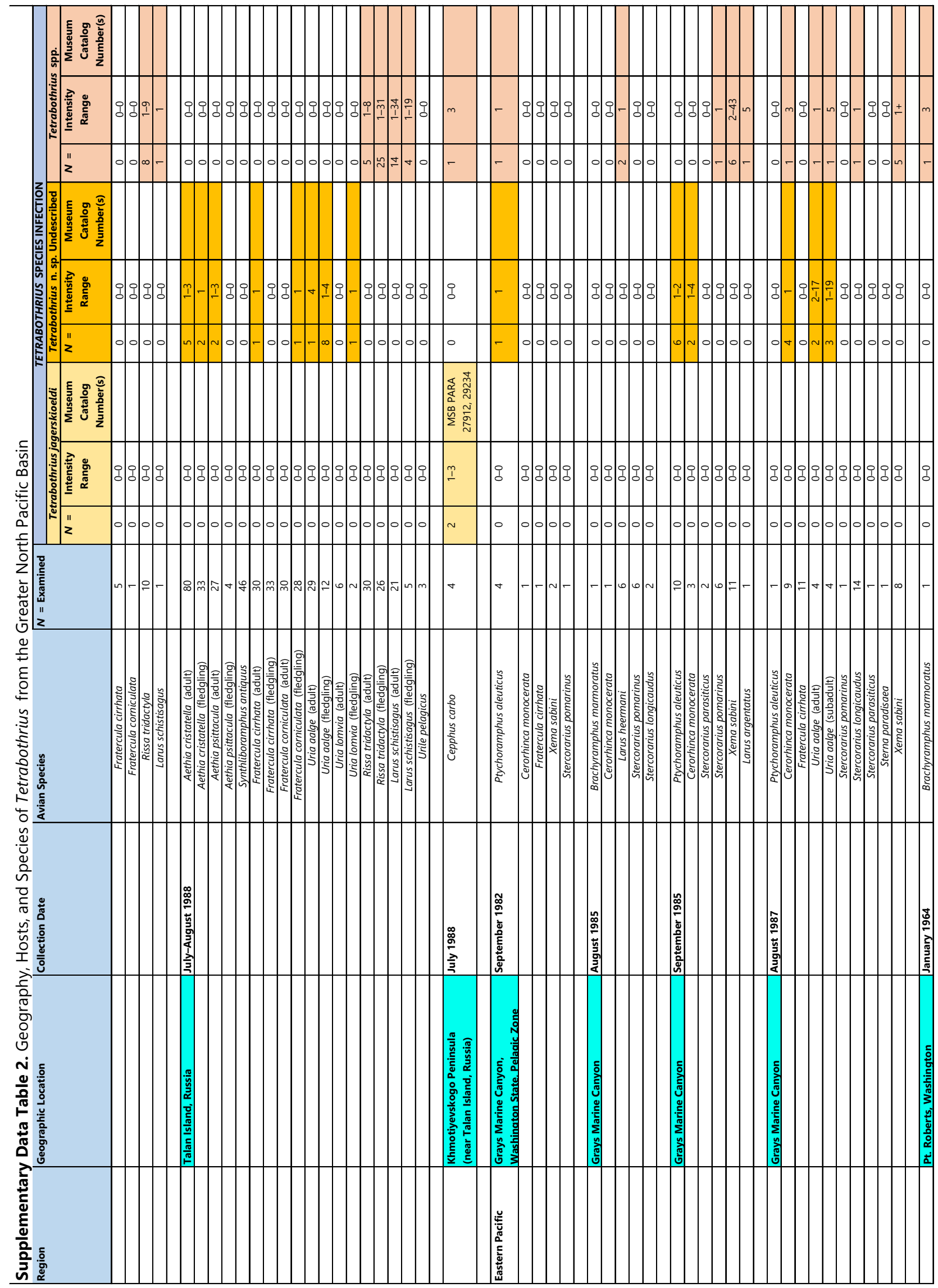




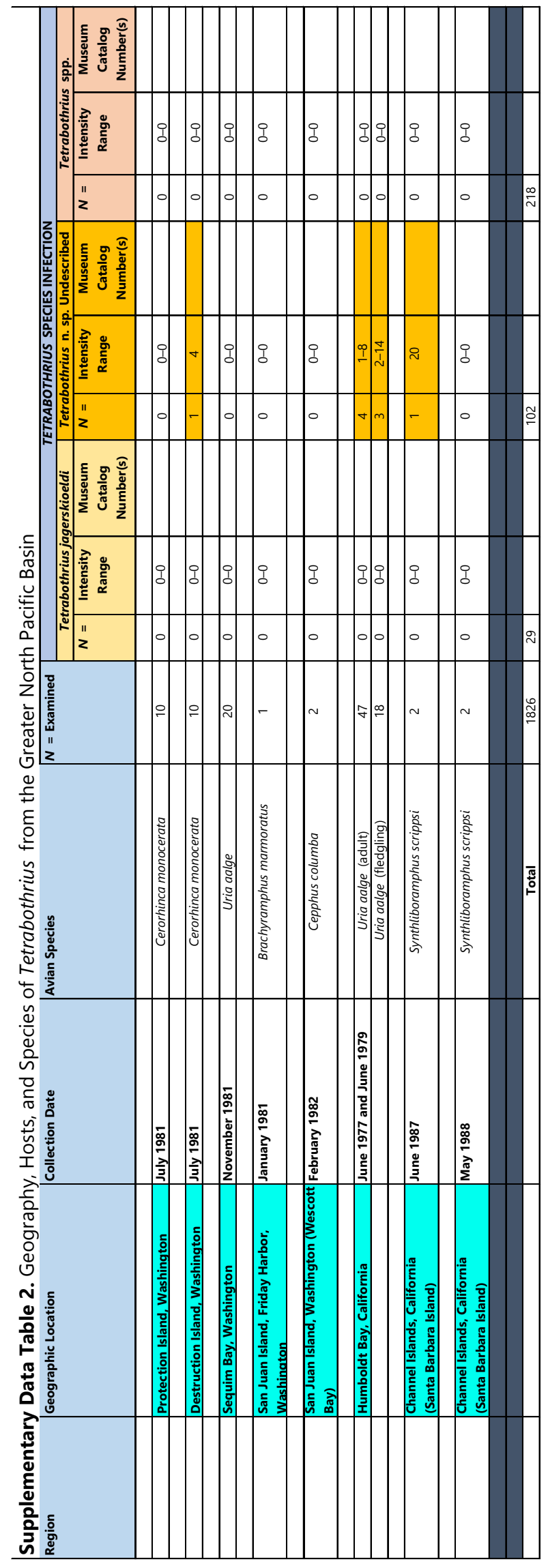




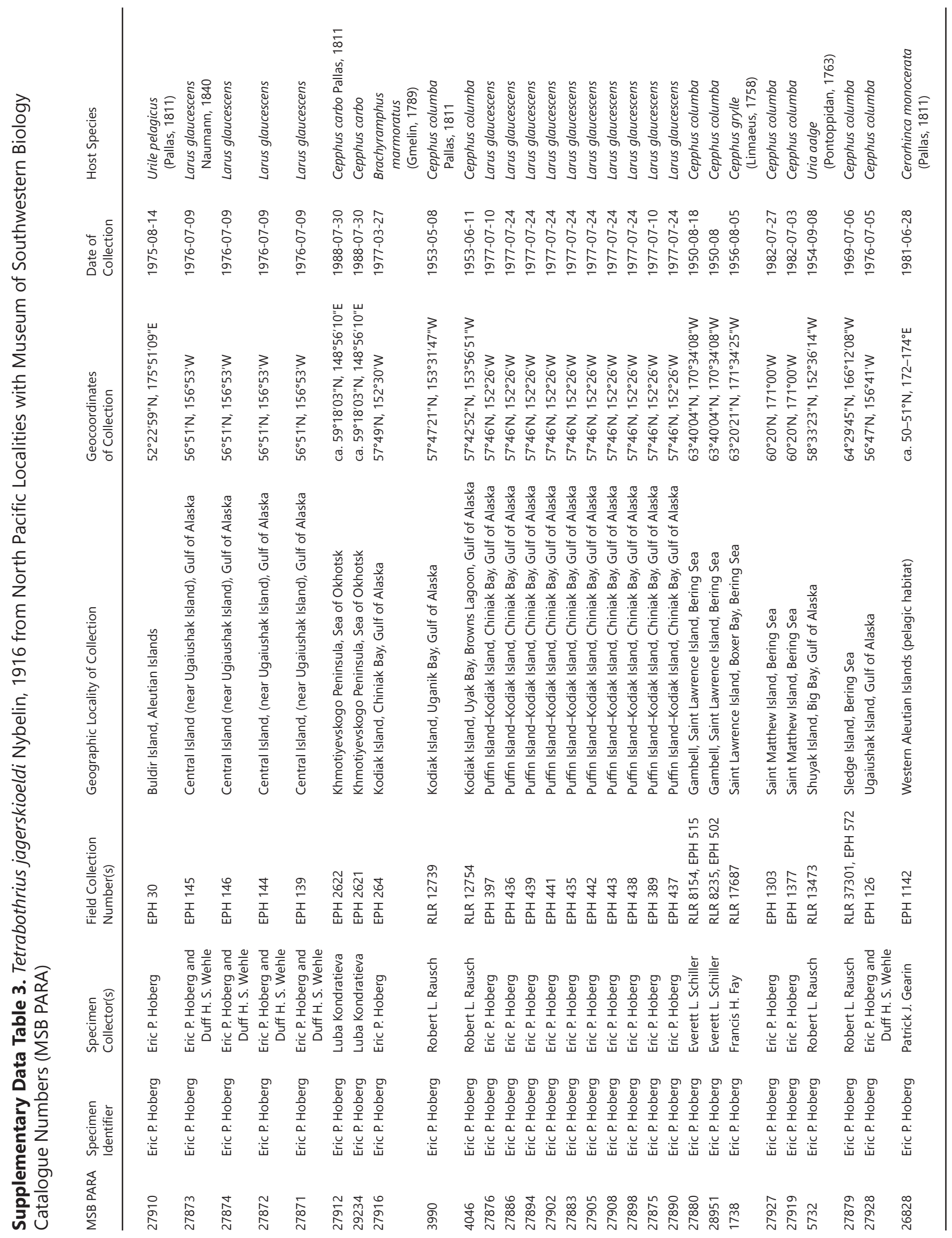




\section{Note:}

Native software versions of all tables and supplementary tables are attached to the main record for this article. 